\title{
家庭用燃料電池を導入した場合の一次エネルギー削減効果に関する研究 \\ STUDY ON PRIMARY ENERGY REDUCTION EFFECT BY INSTALLING HOME-USE FUEL CELL COGENERATION SYSTEM
}

\author{
有波裕 貴 ${ }^{* 1}$, 坂口 淳*2, 赤林 伸 一*3 \\ Yuki ARINAMI, Jun SAKAGUCHI and Shin-ichi AKABAYASHI
}

\begin{abstract}
In this paper, numerical simulation is conducted when total 5.3 million units of SOFC and PEFC are operated nationwide, for power generation configuration and electricity supply amount of general electric utilities before and after the Great East Japan Earthquake. Calculate the annual primary energy reduction amount when a large number of fuel cells are installed and operated. Evaluation of introduction effect of home-use FCCGS as distributed power supply is performed.
\end{abstract}

\begin{abstract}
Keywords : Home-use fuel cell co-generation system, Polymer Electrolyte Fuel Cell, Solid Oxide Fuel Cell, Primary energy consumption, Primary energy consumption unit 家庭用燃料電池コージェネレーションシステム, 固体高分子形燃料電池, 固体酸化物形燃料電池, 一次エネルギー消費量, 一次エネルギー消費原単位
\end{abstract}

\section{1 はじめに}

家庭用燃料電池コージェネレーションシステム（以下、FCCGS） は都市ガス等を改質して燃料となる水素を取り出し、空気中の酸 素と反応させて発電を行うシステムであり、発電時の廃熱を給湯 の一部に利用することで一次エネルギーの利用効率（総合効率約 $80 \%(H H V))$ を向上させることが可能であり、省エネルギー効果 が期待されている。黒木ら ${ }^{1) 、 2)}$ は固体高分子形燃料電池 (Polymer Electrolyte Fuel Ce11、以下 PEFC) 及び PEFC と比較して相対的に 熱出力が少なく発電効率の高い固体酸化物形燃料電池（Solid Oxide Fue1 Ce11、以下 SOFC) を対象とした数值シミュレーションにより、 $\mathrm{PEFC}$ ・SOFC を家庭に導入した場合の省エネルギー効果、 $\mathrm{CO}_{2}$ 排出量 削減効果、光熱費削減効果について検討を行っている。住吉ら ${ }^{3)}$ は SOFC を対象としてシミュレーションを行い、集合住宅において最 適な定格発電出力及び貯湯槽容量を検討している。また余剩排熱を 利用して浴槽に湯張りを行う排熱浴槽出湯運転を提案し、省エネル ギー効果を明らかとしている。湯浅ら ${ }^{4)}$ は集合住宅を対象に世帯 構成や使用機器、入浴による電力・給湯需要のばらつきが SOFC の 一次エネルギー削減効果に与える影響を明らかとしている。家庭用 FCCGS の導入効果に関する既往の研究では、戸建住宅や集合住宅の 住戸単体に FCCGS を設置した場合の検討が殆どであり、全国規模で 燃料電池が普及した場合の一次エネルギー削減効果に関する報告は 筆者らの知る限りない。我が国の将来的なエネルギーベストミック スを考える上でも、家庭用 FCCGS が地域に多数導入された場合の影 響を検討することは重要であると考えられる。

電力会社では太陽光発電、風力発電等の再生可能エネルギー由来
の電力は国の指導により逆潮流注 1) を認めており、年々買取価格が 低下しているものの、電力会社の発電単価に比較して相対的に高い 価格で買い取りを行っている。しかし再生可能エネルギーを用いた 発電設備の運転状況は天候に左右されるため、発電量が不安定であ り、系統の送配電ネットワークの電圧変動に負荷をかける点が問題 である。現状では燃料電池による発電電力は再生可能エネルギー由 来では無いため、電力会社は逆潮流を認めていない。燃料電池が個々 の住宅の使用状況によりばらばらに運転されることで、電力会社の 発電計画に影響を及ぼすことが逆潮流を認めない理由の一つである。 家庭用 FCCGS の稼働状況を電力会社がコントロール出来れば家庭用 FCCGS の余剩電力を逆潮流させ、系統電力の負荷を低減できる可能 性がある。筆者らは既往の研究 ${ }^{5)}$ において東北電力管内の住宅を対 象に 10 万台単位で家庭用燃料電池が普及した場合において、燃料電 池を定格出力で時刻別に稼働させ、余剩電力を逆潮流させた場合の 一次エネルギー消費量及び $\mathrm{CO}_{2}$ 排出量削減効果、系統電力のピーク カット効果を数值シミュレーションにより明らかにしている。

本研究では、東日本大震災前後（2010 年度、2012 年度）の一般 電気事業者 9 社の発電構成・電力供給量を対象として、日本全国 に SOFC 及びPEFC を計 530 万台注2)、6) 設置し、稼働させた場合の数 值シミュレーションを行う。燃料電池を多数配置して稼働させた場 合の年間の一次エネルギー削減量を算出し、家庭用 FCCGS の分散型 電源としての導入効果の評価を行う事を目的とする。更に、燃料電 池が多数配置された場合、系統電力の電力負担が減少するため、相 対的に効率の悪い発電設備の稼働が減少し、系統電力の一次エネル ギー消費原単位注3) も減少すると考えられ、家庭用 FCCGS を導入し
*1 新潟大学工学部工学科建築学プログラム 助教・博士 (工学

*2 新潟県立大学国際地域学部国際地域学科 教授・博士 (工学)

*3 新潟大学大学院自然科学研究科 教授.工博
Assist. Prof, Architecture Program, Faculty of Eng. Niigata University, DrEng. Prof., Faculty of International Studies and Regional Development, Dept. of International Studies and Regional Development, University of Niigata Prefecture, Dr.Eng. Prof., Graduate School of Science and Technology, Niigata University, Dr.Eng. 
た住宅以外の住宅及び非住宅部門の電力消費においても一次エネル ギーが削減される可能性がある。本研究ではこの点についても考慮 する。この点について検討された建築分野の既往の論文は存在しな いと考えられる。家庭用 FCCGS が全国に多数設置されることにより、 系統電力の一次エネルギー消費原単位が変化することを考慮するこ とは、単一の住宅を対象とした家庭用 FCCGS の導入によるエネルギー 消費量の変化を検討することでは困難であると考えられる。

本報は 2014 年度日本建築学会大会 $(\text { 近畿 })^{7}$. 8 、2 2015 年度日本建 築学会大会 (東海) ${ }^{9}$ 、10) において発表した内容に新たな検討と修正 を加え、再構成したものである。

\section{2 解析概要}

\section{1 対象地域}

対象地域は日本国内の沖縄電力を除く一般電気事業者 9 社の電力 供給範囲ごとの 9 地域とし、それぞれの戸建住宅及び集合住宅を対 象住宅とする。空調負荷や給水温度等の算出には各府県庁所在地注 4$)$ の値を代表值として用いる。

\section{2 対象住宅種別・仕様}

図 1 に住宅モデル平面図を示す。戸建住宅の住宅モデルには日本 建築学会住宅用標準問題モデル ${ }^{11)}$ を、集合住宅には片廊下型板状 タイプの中間階・中間住戸モデルを用いる。 $\mathrm{U}_{\mathrm{a}}$ 值は全国で統一注5) 戸建住宅 : $0.82 \mathrm{~W} /\left(\mathrm{m}^{2} \cdot \mathrm{K}\right)$ 、集合住宅 : $0.68 \mathrm{~W} /\left(\mathrm{m}^{2} \cdot \mathrm{K}\right)$ とした。

\section{3 世帯数 - 家庭用 FCCGS 設置住戸数}

図 2 に対象エリア毎の家庭用 FCCGS 設置住戸数を示す。ガス事業便 覧 ${ }^{12)}$ によるメーター調定戸数及び LP ガス消費世帯数より、都道府県毎 のガス使用世帯数を算出する。算出した都道府県毎のガス使用世帯数 の全体に対する比率及び 2030 年度の FC 普及目標台数 (530 万台) より、 都道府県毎の家庭用 FCCGS 設置住戸数を求める。更に、各都道府県の 設置住戸数を各都道府県の戸建住宅・集合住宅の一般世帯数 ${ }^{13)}$ の比率 で按分することで算出する。2012 年度時点における全国の世帯数は約 4800 万世帯であり、本研究で想定した 530 万台が普及した場合の家庭用 FCCGS の設置率は各都道府県の戸建住宅、集合住宅ともに約 $11 \%$ である。

\section{4 生活スケジュール}

生活スケジュール作成には生活スケジュール自動生成プログラム SCHEDULE $^{14)}$ ( 以下 SCHEDULE) を用いる。世帯人員数は戸建住宅 3 人 ( 夫婦 +小学生)、集合住宅 2 人 ( 夫婦のみ) 及び、戸建住宅 4 人 ( 夫 婦 + 小学生 +中学生)、集合住宅 3 人 (夫婦 +小学生) の 2 パター ン注 6) とし、冬季・夏季・中間期の平日・休日についての在室パターン、 照明及び各種機器 (テレビ等) の電力消費スケジュールを作成する。

\section{5 熱負荷計算と電力消費スケジュール}

表 1 に対象住宅の空調・換気条件、図 3 に電力消費スケジュール の一例を示す。年間熱負荷計算には熱負荷シミュレーションソフト TRNSYS Ver. 16 を使用し、各都道府県における各対象住宅の 1 時間毎 の空調負荷を算出する。換気は第一種換気とし、熱交換は行わない設 定とした。気象データには気象庁 ${ }^{15)}$ が web 上で公表している 1 時間 毎の気象データ、照明・各種機器発熱データは SCHEDULE で算出した データを用いる。気象データは 2010 年度と 2012 年度を用いる。空調 スケジュールはSCHEDULEを使用せず、在室時空調として空調設定温 度、空調期間を TRNSYS で設定する。空調に使用するエアコンは暖冷 房平均 COP を $3.0^{\text {i: } 7) 、 16)}$ とし、空調時の 1 時間当たりの消費電力を求め、
SCHEDULE で算出した照明・各種機器電力ケジュールに加算し、世帯人 員数・都道府県毎の電力消費スケジュールを求める。

\section{6 給水温度と給湯スケジュール}

表 2 に世帯人員数別の給湯量 ${ }^{177}$ を、表 3 に暖房度日による地域区 分と給水温度に関する回帰係数を、表 4 に関東地方における月平均 外気温と月平均給水温度を示す。給水温度を算出する際の気象デー 夕には気象庁が web 上で公表している 1 時間毎の外気温データを用 いる。気象データを基に日平均外気温度を求め、暖房度日（D18-18） を算出し地域区分 ${ }^{18)}$ を求める。又、月平均外気温を算出し、地域区 分毎の回帰式により月平均給水温度を算出する。月平均給水温度の 算出には以下の式 $(1)^{19)}$ を用いる。

$$
T_{c w \text { month }}=a T_{\text {air month }}+b \quad \cdots(1)
$$

算出した給水温度及び表 2 に示す世帯人数別日給湯量 $\left(40^{\circ} \mathrm{C}\right)$ を 基に、貯湯温度 $\left(70^{\circ} \mathrm{C}\right)$ における月別日積算貯湯量を算出寸る。作 成した給湯条件及び 5 分毎の給湯スケジュール $\left(40^{\circ} \mathrm{C}\right)$ を基に貯湯 温度 $\left(70^{\circ} \mathrm{C}\right)$ におけるスケジュールを作成寸る。図 4 にスケジュー ルの一例を示す。

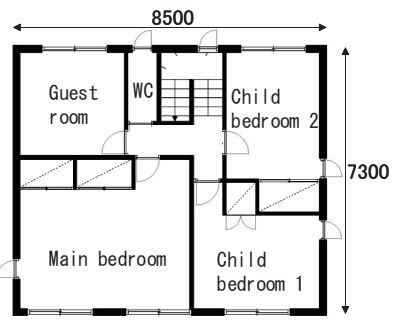

(2) Detached house $2 \mathrm{~F}$

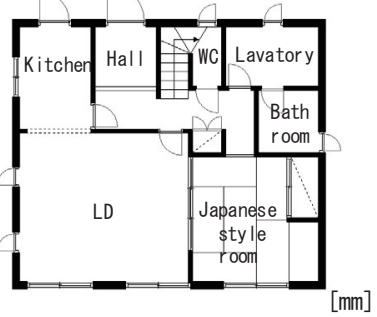

(1) Detached house $1 \mathrm{~F}$

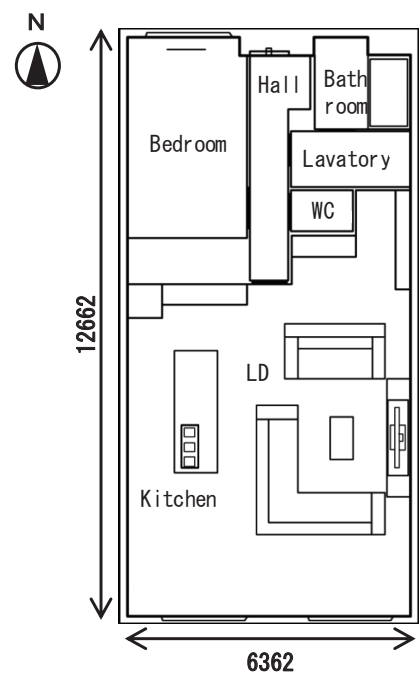

(3) Apartment house
Fig. 1 Building model plan

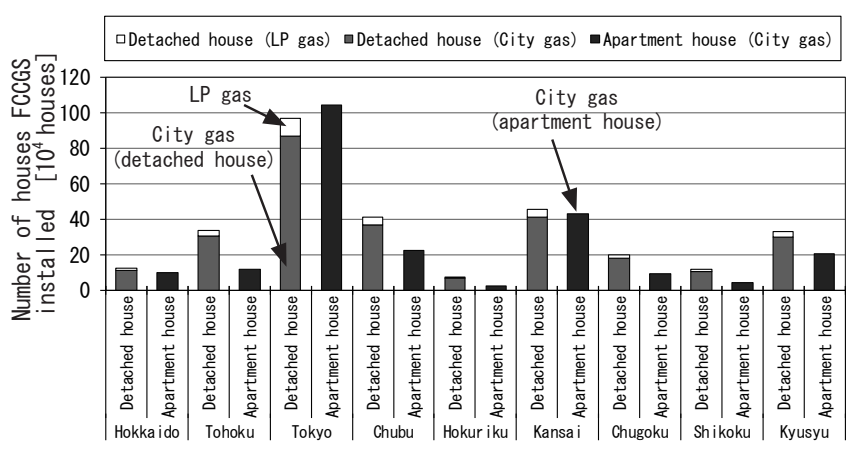

Fig. 2 Number of houses FCCGS installed in each area

Table 1 Air conditioning and ventilation conditions

\begin{tabular}{r|c|c|c}
\hline \multirow{3}{*}{ Air conditioning } & \multirow{2}{*}{ Cooling } & Setting temperature & $28\left[{ }^{\circ} \mathrm{C}\right]$ \\
\cline { 2 - 3 } & & Period & From june to september \\
\cline { 2 - 3 } & \multirow{2}{*}{ Heating } & Setting temperature & $20\left[{ }^{\circ} \mathrm{C}\right]$ \\
\cline { 2 - 3 } & Period & From november to march \\
\hline \multicolumn{2}{|c|}{ Air change rate } & $0.5[1 / \mathrm{h}]$ \\
\hline \multicolumn{2}{|c|}{ Range hood flow rate } & $300\left[\mathrm{~m}^{3} / \mathrm{h}\right]$ \\
\hline
\end{tabular}


3 一般電気事業者の計算条件

\section{1 発電設備の概要}

表 5 に一般電気事業者の発電設備容量 (2012 年度) を示す。火力 発電設備において発電単価は、石炭 $\rightarrow$ LNG・天然ガス $\rightarrow$ 石油系の順 で高くなる為、各一般電気事業者の供給電力の内、ベース電力は石 炭を用いた汽力発電、ミドル電力は LNG 及び天然ガスを燃料とした コンバインドサイクル発電で賄い、マージナル電力は石油系の汽力 発電で賄うと考えられる。尚、本研究では沖縄県及び沖縄電力を対 象としていない。これは沖縄電力が原子力発電設備を所有してお らず、震災前後で発電構成に影響が見られない為である。

\section{2 電力供給実績值}

解析対象は 2010 年度（原発あり）と 2012 年度（原発なし）とし、 各一般電気事業者が Web ページ上 ${ }^{20 \sim 28)}$ で公表している 1 時間毎 の電力供給実績データを用いる。尚、四国電力は 2012 年 7 月以降 のデータしか公表されていない為、それ以前のデータは中国電力 の電力供給実績值から求めた回帰式注 8 ）（決定係数 $\mathrm{R}^{2}=0.971 ＼mathrm{~ ） 用 ~}$ いて、四国電力の仮想の電力供給值を求めて計算を行う。

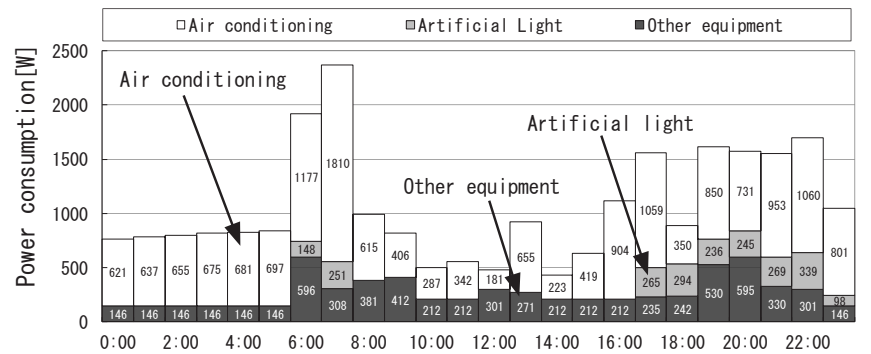

(1) Detached house (coldest day in winter)

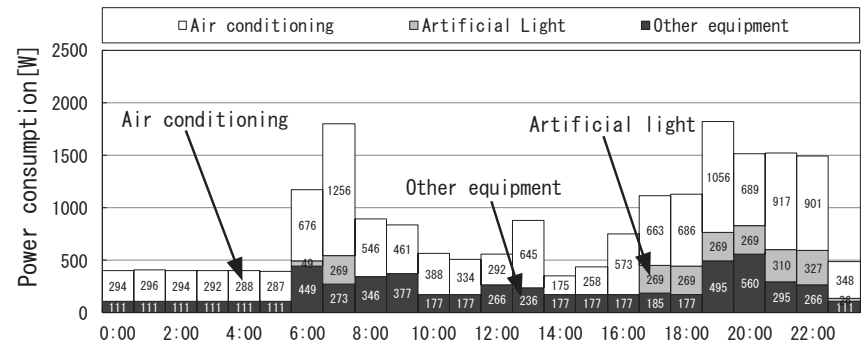

(2) Apartment house (coldest day in winter)

Fig. 3 Example of power consumption schedule (Tokyo)

Table 2 Amount of hot water supply for each number of household members

\begin{tabular}{c|c|c|c|c|c}
\hline $\begin{array}{c}\text { Number of } \\
\text { housefold members }\end{array}$ & 1 person & 2 people & 3 people & 4 people & 5 people \\
\hline $\begin{array}{c}\text { Hot water supply } \\
\left(40^{\circ} \mathrm{C}\right)[\mathrm{L} /(\text { day })]\end{array}$ & 186.8 & 267.4 & 399.4 & 446.9 & 427.0 \\
\hline
\end{tabular}

Table 3 Region classification by heating degree days and water supply temperature regression coefficient

\begin{tabular}{|c|c|c|c|}
\hline \multirow{2}{*}{$\begin{array}{l}\text { Region classification in } \\
\text { standards of judgment for } \\
\text { residential construction clients }\end{array}$} & \multirow{2}{*}{$\begin{array}{l}\text { Heating degree days } \\
\text { (D18-18) }\end{array}$} & \multicolumn{2}{|c|}{ Regression coefficient } \\
\hline & & a & b \\
\hline 1 & 4500 degree days or more & \multirow[b]{2}{*}{0.6639} & \multirow[b]{2}{*}{3.466} \\
\hline 2 & $\begin{array}{l}3500 \text { degree days or more and } \\
\text { less than } 4500 \text { degrees days }\end{array}$ & & \\
\hline 3 & $\begin{array}{l}3000 \text { degree days or more and } \\
\text { less than } 3500 \text { degrees days }\end{array}$ & \multirow{2}{*}{0.6054} & \multirow{2}{*}{4.515} \\
\hline 4 & $\begin{array}{l}2500 \text { degree days or more and } \\
\text { less than } 3000 \text { degrees days }\end{array}$ & & \\
\hline 5 & $\begin{array}{l}2000 \text { degree days or more and } \\
\text { less than } 2500 \text { degrees days }\end{array}$ & 0.8660 & 1.665 \\
\hline 6 & $\begin{array}{l}1500 \text { degree days or more and } \\
\text { less than } 2000 \text { degrees days }\end{array}$ & 0.8516 & 2.473 \\
\hline 7 & $\begin{array}{l}500 \text { degree days or more and } \\
\text { less than } 1500 \text { degrees days }\end{array}$ & 0.9223 & 2.097 \\
\hline 8 & Less than 500 degrees days & 0.6921 & 7.167 \\
\hline
\end{tabular}

Table 4 Monthly average outside temperature and monthly average water supply temperature in Kanto region (2012)
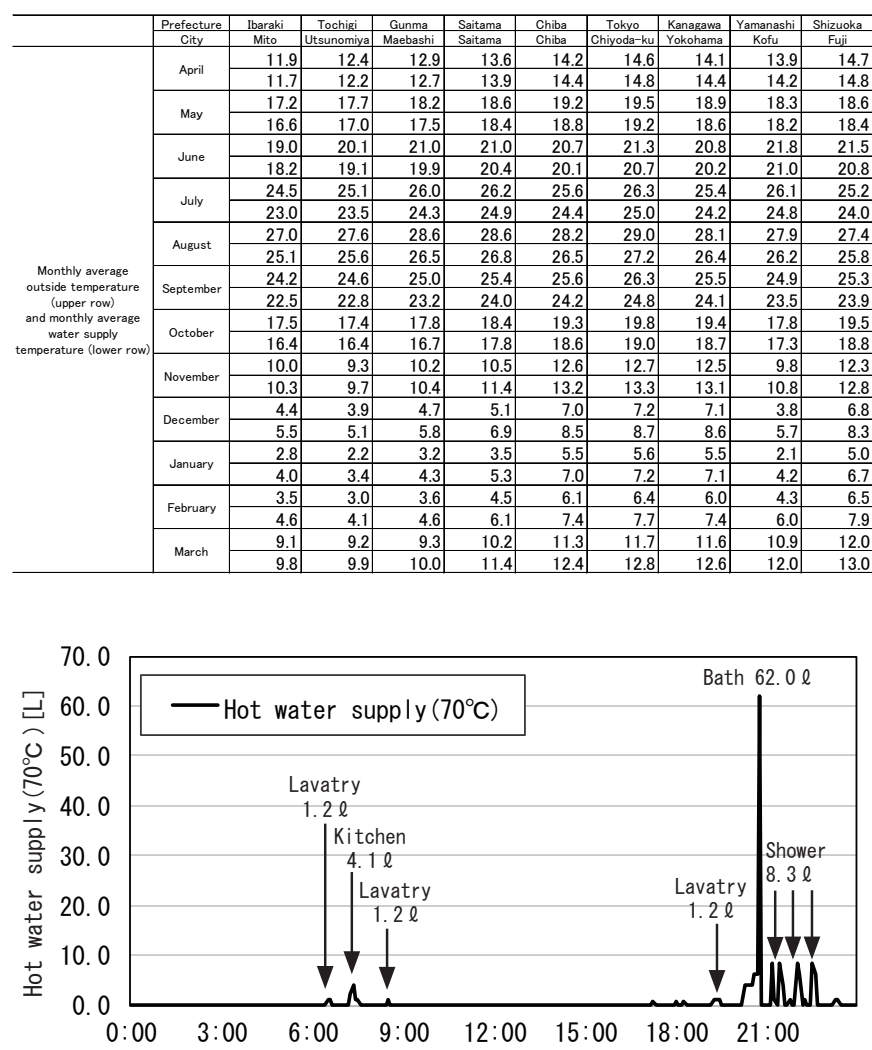

Fig. 4 Example of hot water supply schedule (Tokyo, detached house, 3 people, 2012)

Table 5 Power generation capacity of general electric utilities in 2012

\begin{tabular}{|c|c|c|c|c|c|c|c|c|c|}
\hline \multirow{2}{*}{$\begin{array}{l}\text { Power generation } \\
\text { capacity }\left[10^{4} \mathrm{~kW}\right]\end{array}$} & \multicolumn{3}{|c|}{ Tharmal power generation } & \multirow{2}{*}{$\begin{array}{l}\text { Hydro- } \\
\text { electricity }\end{array}$} & \multirow{2}{*}{$\begin{array}{l}\text { Pumped-storage } \\
\text { hydroelectricity }\end{array}$} & \multirow{2}{*}{$\begin{array}{l}\text { Nuclear } \\
\text { power } \\
\text { generation }\end{array}$} & \multirow{2}{*}{$\begin{array}{l}\text { Renewable } \\
\text { energy } \\
\text { generation }\end{array}$} & \multirow{2}{*}{$\begin{array}{c}\text { Emergency } \\
\text { installation } \\
\text { power supply }\end{array}$} & \multirow{2}{*}{ Total } \\
\hline & Coal & LNG & Petroleum & & & & & & \\
\hline Hokka i do & 241 & 171 & 181 & 81 & 100 & 207 & 3 & 15 & 998 \\
\hline Tohoku & 68 & 438 & 1004 & 195 & 46 & 466 & 23 & 76 & 2315 \\
\hline Tokyo & 460 & 3498 & 1211 & 218 & 681 & 1731 & 3 & 104 & 7906 \\
\hline Chubu & 410 & 1947 & 951 & 198 & 466 & 500 & 4 & 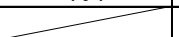 & 4475 \\
\hline Hokur iku & 290 & 42 & 231 & 193 & 0 & 175 & 1 & 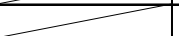 & 932 \\
\hline Kansai & 180 & 1117 & 1080 & 328 & 492 & 977 & 2 & 7 & 4182 \\
\hline Chugoku & 316 & 217 & 409 & 99 & 212 & 540 & 1 & $\infty$ & 1793 \\
\hline Shikoku & 125 & 224 & 94 & 96 & 69 & 202 & 1 & 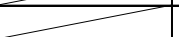 & 809 \\
\hline Kyusyu & \begin{tabular}{|l|}
424 \\
\end{tabular} & 489 & 468 & 192 & 230 & 685 & 31 & 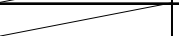 & 2519 \\
\hline
\end{tabular}




\section{3 発電所稼動順位の作成}

表 6 に一般電気事業者 9 社の総合ロス（所内ロス + 送配電ロス + 変電ロス) を示す。総発電電力と受電端一次エネルギー消費原単 位は、発電機の稼働順位をベース電源である (1)水力 ${ }^{29)}$ 、(2)原子力、 (3)火力 (石炭) 、消費電力の変動に対応する (4)火力 (LNG、石油 )、ピー ク電源(5)揚水と設定し、火力では低発電単価（石炭）、高発電効率 (LNG (MACC、ACC、CC、汽力) 、石油順) の順に発電機が稼働すると 仮定する。各設備の発電効率 (HHV 基準) 及び総合ロスを基に受電

Table 6 Comprehensive loss of 9 general electric utilities

\begin{tabular}{c|c|c|c|c|c|c|c|c|c}
\hline $\begin{array}{c}\text { Comprehensive } \\
\text { loss[\%] }\end{array}$ & Hokkaido & Tohoku & Tokyo & Chubu & Hokur iku & Kansai & Chugoku & Shikoku & Kyusyu \\
\hline 2010 & 11.9 & 8.8 & 7.8 & 8 & 9.4 & 7.9 & 8.4 & 9.8 & 7.7 \\
\hline 2012 & 10.7 & 8.4 & 7.1 & 7.7 & 9.4 & 7.5 & 8.3 & 8.9 & 7.2 \\
\hline
\end{tabular}

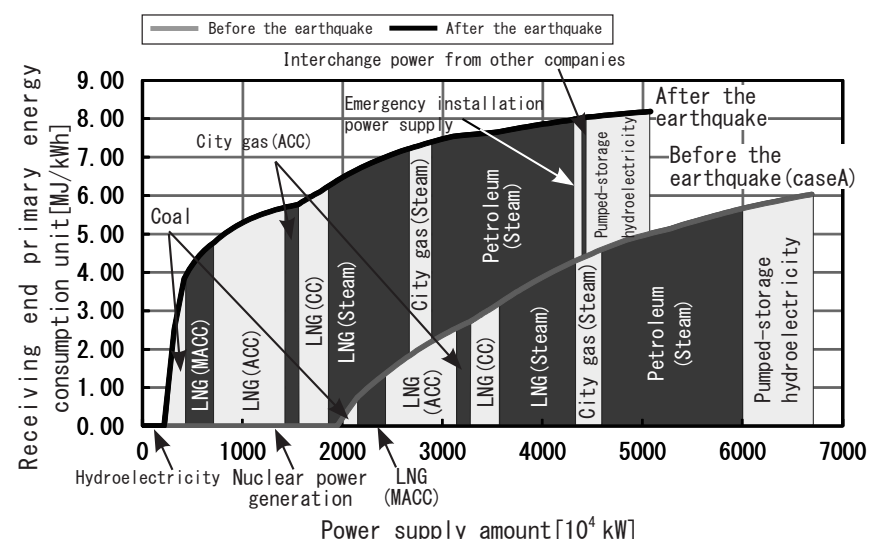

(1) Comparison of before and after the earthquake

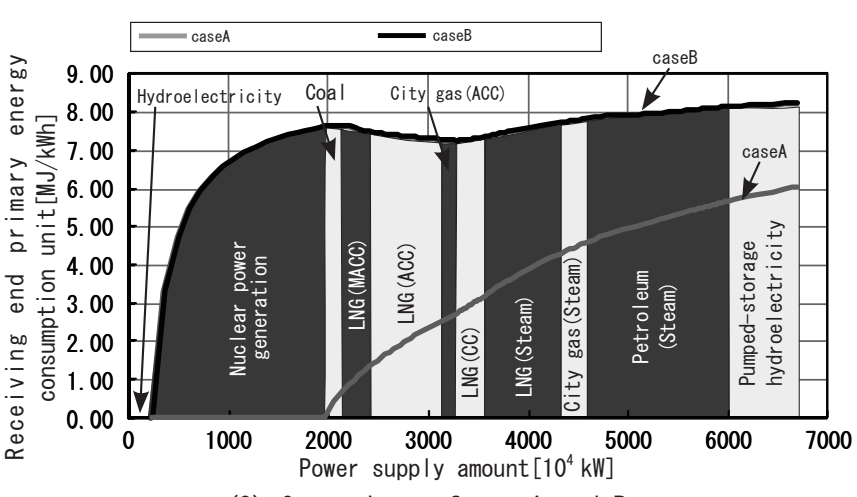

(2) Compar ison of caseA and B

Fig. 5 Power supply amount and receiving end primary energy consumption unit in TEPCO
端発電効率を算出する。発電効率を電力供給量に応じた発電設備の 容量で加重平均することで、各時刻の系統電力の電力供給量に対す る受電端供給量別一次エネルギー消費原単位を算出する。尚、水力 発電及び原子力発電の設備稼働率は年間を通して $100 \%$ と仮定して いる。水力発電の発電端一次エネルギー消費原単位は $0[M J / k W h]$ とする。原子力発電注9) では、caseA として発電端一次エネルギー 消費原単位を $0[\mathrm{MJ} / \mathrm{kWh}$ とする場合と、caseB として発電端一次エ ネルギー消費原単位を我が国の火力発電平均発電効率と同等として 計算を行う場合を設定する。一例として、図 5 に東京電力管内の電 力供給量と受電端一次エネルギー消費原単位の関係を示す。

\section{4 供給量別一次エネルギー原単位}

図 6 に 2012 年度における東京電力管内の電力供給量実績值と供 給量別一次エネルギー消費原単位を示す。冬季最寒日 $(2013 / 2 / 24)$ において電力供給量の最大值は 18 時に $3,292[\mathrm{kWh}]$ (一次エネル ギー消費原単位：7.59[MJ/kWh])、最小值は 4 時に $2,355[\mathrm{kWh}]$ （一次エネルギー消費原単位：6.96[MJ/kWh]）となり、一次エネ ルギー消費原単位の日較差は $0.63[\mathrm{MJ} / \mathrm{kWh}]$ となる。夏季最暑日 (2012/7/24) において電力供給量の最大値は 14 時に 4, 184[kWh] （一次エネルギー消費原単位：7.93[MJ/kWh]）、最小值は 4 時に 2,519[kWh]（一次エネルギー消費原単位：7.15[MJ/kWh]）となり、 一次エネルギー消費原単位の日較差は $0.78[\mathrm{MJ} / \mathrm{kWh}]$ となる。

図 7 に東京電力管内の供給量別一次エネルギー消費原単位 (2012 年度）の年変化を示す。供給量別一次エネルギー消費原単位は概 放 $6.6 \sim 8.1[\mathrm{MJ} / \mathrm{kWh}]$ 程度で推移しており、電力供給量の比較的

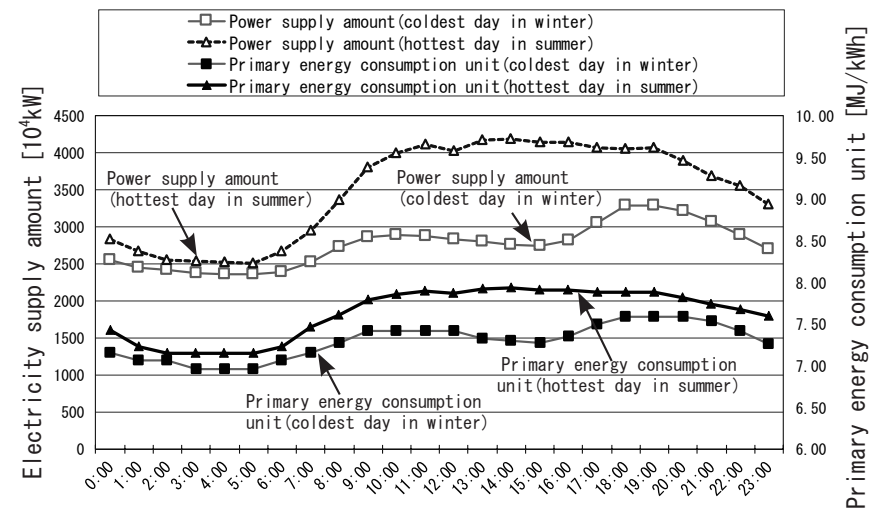

Fig. 6 Power supply amount and Primary energy consumption unit in TEPCO (2012)

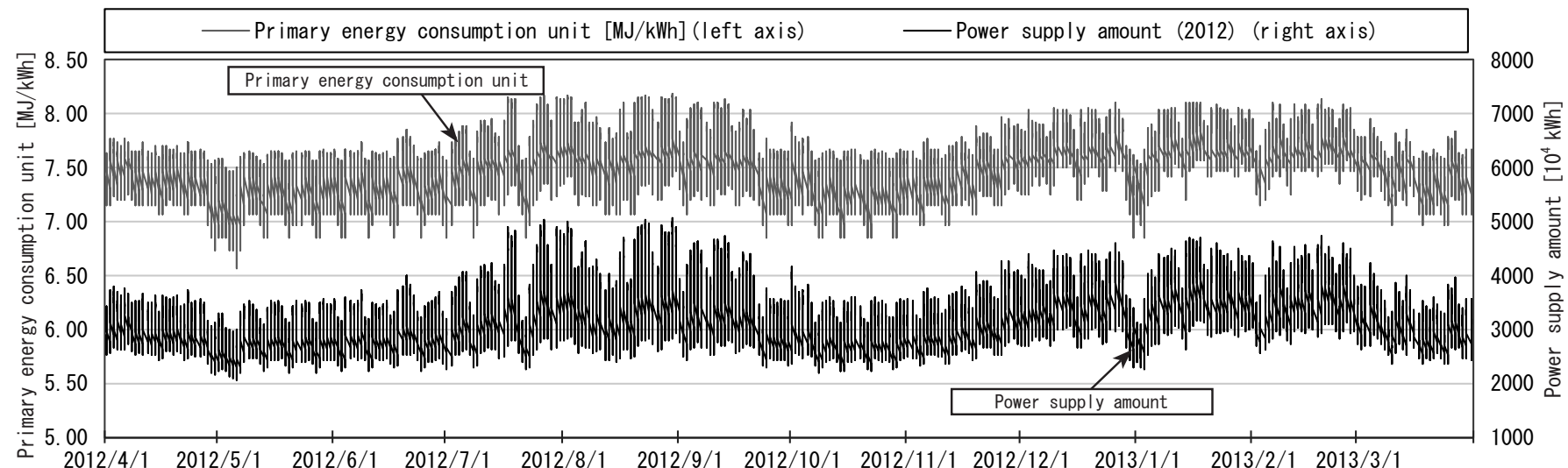

Fig. 7 Primary Energy Consumption Unit in TEPCO (2012) 
少ない中間期及び休日に小さく、電力供給量の比較的多い冬季 · 夏季及び平日に大きくなる。特に 5 月の大型連休や 8 月の盆休み 期間、年末年始では比較的顕著に一次エネルギー消費原単位が減 少する。尚、年平均值 ${ }^{\text {泣 }^{10)}}$ は 7.61[MJ/kWh] である。

\section{4 家庭用 FCCGS の計算条件}

表 7 に家庭用 FCCGS の性能・仕様を、表 8 に家庭用 FCCGS の運転 条件を、表 9 に PEFC の起動時刻を、図 8 に家庭用 FCCGS の部分負 荷時能力曲線を示す。セルスタックの種類は固体高分子形 (PE) と 固体酸化物形 (SO) の 2 種類とし、PEFC は PEFC-I ( 燃料: 都市ガス) と PEFC- II (燃料：LP ガス)、SOFCはSOFC-I (現行仕様)及び SOFC- II ( 将来仕様 ) の計 4 機種を計算対象とする。本稿の燃料電 池の発電効率、熱回収効率等の効率值は全て高位発熱量基準 (HHV) で表記する。家庭用 FCCGS の稼働シミュレーションは 5 分刻みで行 う。SOFC- II はタンク貯湯量が 30L の場合と $90 \mathrm{~L}$ の場合の計算を行 う。PEFC は 1 日 1 回起動停止を行う為、対象地域・季節・住宅種別・ 運転方法毎に起動時刻注 11 を設定する。起動時刻は各地域の代表都 市において冬季、夏季、中間期それぞれの最寒日（日平均外気温が

Table 7 Performance and specifications of Home-use FCCGS

\begin{tabular}{|c|c|c|c|c|c|}
\hline \multicolumn{2}{|c|}{ Fue I cell type } & PEFC-I & PEFC- II & SOFC-I & SOFC- II \\
\hline \multicolumn{2}{|c|}{ Performance level } & \multicolumn{3}{|c|}{ Current specification } & $\begin{array}{c}\text { Future } \\
\text { specifications }\end{array}$ \\
\hline \multicolumn{2}{|c|}{ Fue I type } & City gas & LP Gas & \multicolumn{2}{|c|}{ City gas } \\
\hline \multirow{3}{*}{$\begin{array}{c}\text { Rated efficiency } \\
\text { (HHV) }\end{array}$} & Power generation & $35.2 \%$ & $34.3 \%$ & $42.0 \%$ & $49.6 \%$ \\
\hline & Heat recovery & $50.6 \%$ & $50.5 \%$ & $39.2 \%$ & $27.1 \%$ \\
\hline & Total & $85.8 \%$ & $84.8 \%$ & $81.2 \%$ & $76.7 \%$ \\
\hline \multirow{2}{*}{$\begin{array}{c}\text { Rating capability } \\
{[\mathrm{kW}]}\end{array}$} & Power generation & 0.75 & 0.70 & 0.70 & 0.70 \\
\hline & Heat recovery & 1.08 & 1.00 & 0.65 & 0.38 \\
\hline \multicolumn{2}{|c|}{ Gas consumption [kW] } & 2.13 & 2.04 & 1.67 & 1.41 \\
\hline \multicolumn{2}{|c|}{ Hot water storage tank capacity [L] } & 147 & 200 & 90 & $30 / 90$ \\
\hline \multicolumn{2}{|c|}{ Start-up time [min] } & \multicolumn{2}{|c|}{50} & \multicolumn{2}{|r|}{-} \\
\hline \multicolumn{2}{|c|}{ Fan power consumption [W] } & \multicolumn{2}{|c|}{-} & \multicolumn{2}{|r|}{4.8} \\
\hline \multicolumn{2}{|c|}{ Hot water storage temperature $\left[{ }^{\circ} \mathrm{C}\right]$} & \multicolumn{4}{|c|}{70} \\
\hline
\end{tabular}

Table 8 Operating condi
最低を記録した日）を代表日として決定する。尚、9 地域毎の代表 都市は各電力管内において最寒日の日平均外気温が最も低い都市と する。SOFC 設置住戸では、貯湯タンク容量を満たした後の余剩熱 はラジェータ（ファンの消費電力： $4.8[\mathrm{~W}]$ ) で大気に放出する。

Table 9 PEFC startup time (2012)

(1) Coldest day in winter season

\begin{tabular}{|c|c|c|c|c|c|}
\hline & \multirow[b]{2}{*}{$\begin{array}{l}\text { Coldest day } \\
\text { in winter }\end{array}$} & \multicolumn{2}{|c|}{ Operation method 1} & \multicolumn{2}{|c|}{ Operation method 2} \\
\hline & & $\begin{array}{c}\text { Detached } \\
\text { house }\end{array}$ & $\begin{array}{c}\text { Apartment } \\
\text { house }\end{array}$ & $\begin{array}{c}\text { Detached } \\
\text { house }\end{array}$ & $\begin{array}{c}\text { Apartment } \\
\text { house }\end{array}$ \\
\hline Hokkaido & $2012 / 12 / 26$ & $7: 40$ & $10: 30$ & $7: 40$ & $9: 50$ \\
\hline Tohoku & $2012 / 12 / 25$ & $8: 20$ & $11: 00$ & $8: 00$ & $10: 10$ \\
\hline Tokyo & $2013 / 2 / 24$ & $8: 30$ & $12: 00$ & $5: 40$ & $10: 10$ \\
\hline Chubu & $2013 / 1 / 4$ & $5: 40$ & $12: 10$ & $4: 30$ & $9: 10$ \\
\hline Hokur iku & $2013 / 2 / 24$ & $5: 50$ & 12:10 & $5: 20$ & $10: 10$ \\
\hline Kansai & $2013 / 1 / 3$ & $8: 10$ & $12: 10$ & $5: 10$ & $10: 20$ \\
\hline Chugoku & $2013 / 2 / 7$ & $9: 00$ & $12: 10$ & $5: 40$ & $10: 00$ \\
\hline Shikoku & $2013 / 2 / 7$ & $9: 30$ & $12: 10$ & $4: 20$ & $9: 00$ \\
\hline Kyusyu & $2013 / 2 / 7$ & $9: 20$ & $12: 10$ & $5: 10$ & 10:00 \\
\hline
\end{tabular}

(2) Coolest day in summer season

\begin{tabular}{|c|c|c|c|c|c|}
\hline & \multirow{2}{*}{$\begin{array}{l}\text { Coolest day } \\
\text { in summer }\end{array}$} & \multicolumn{2}{|c|}{ Operation method 1} & \multicolumn{2}{|c|}{ Operation method 2} \\
\hline & & $\begin{array}{c}\text { Detached } \\
\text { house }\end{array}$ & $\begin{array}{c}\text { Apartment } \\
\text { house }\end{array}$ & $\begin{array}{c}\text { Detached } \\
\text { house }\end{array}$ & $\begin{array}{l}\text { Apartment } \\
\text { house }\end{array}$ \\
\hline Hokkaido & $2012 / 6 / 13$ & $9: 50$ & $12: 10$ & $0: 55$ & $3: 30$ \\
\hline Tohoku & $2012 / 6 / 13$ & $10: 05$ & $12: 10$ & $0: 55$ & $5: 40$ \\
\hline Tokyo & $2012 / 6 / 12$ & $10: 40$ & $12: 10$ & $2: 20$ & $11: 30$ \\
\hline Chubu & $2012 / 6 / 22$ & $10: 20$ & $12: 10$ & $0: 55$ & $5: 15$ \\
\hline Hokur iku & $2012 / 6 / 1$ & $11: 10$ & $12: 10$ & $1: 00$ & $7: 10$ \\
\hline Kansai & $2012 / 6 / 21$ & $11: 50$ & $12: 10$ & $1: 00$ & $7: 00$ \\
\hline Chugoku & $2012 / 6 / 1$ & $11: 00$ & $12: 10$ & $1: 00$ & $7: 00$ \\
\hline Shikoku & $2012 / 6 / 5$ & $12: 10$ & $12: 10$ & $5: 20$ & $10: 20$ \\
\hline Kyusyu & $2012 / 9 / 22$ & $12: 10$ & $12: 10$ & $1: 00$ & $8: 30$ \\
\hline
\end{tabular}

(3) Coldest day in moderate season

\begin{tabular}{|c|c|c|c|c|c|}
\hline & \multirow{2}{*}{$\begin{array}{l}\text { Coldest day } \\
\text { in moderate } \\
\text { season }\end{array}$} & \multicolumn{2}{|c|}{ Operation method 1} & \multicolumn{2}{|c|}{ Operation method 2} \\
\hline & & $\begin{array}{c}\text { Detached } \\
\text { house }\end{array}$ & $\begin{array}{c}\text { Apartment } \\
\text { house }\end{array}$ & $\begin{array}{l}\text { Detached } \\
\text { house }\end{array}$ & $\begin{array}{c}\text { Apartment } \\
\text { house }\end{array}$ \\
\hline Hokka ido & $2012 / 4 / 7$ & $5: 45$ & $12: 10$ & $0: 55$ & $1: 40$ \\
\hline Tohoku & $2012 / 4 / 7$ & $6: 40$ & $12: 10$ & $0: 55$ & $1: 25$ \\
\hline Tokyo & $2012 / 4 / 7$ & $8: 40$ & $12: 10$ & $0: 55$ & $2: 05$ \\
\hline Chubu & $2012 / 4 / 7$ & $6: 45$ & $12: 10$ & $0: 55$ & $1: 20$ \\
\hline Hokuriku & $2012 / 4 / 7$ & $8: 20$ & $12: 10$ & $1: 00$ & $1: 10$ \\
\hline Kansai & $2012 / 4 / 7$ & $8: 55$ & $12: 10$ & $0: 55$ & $2: 55$ \\
\hline Chugoku & $2012 / 4 / 7$ & $8: 55$ & $12: 10$ & $0: 55$ & $2: 55$ \\
\hline Shikoku & $2012 / 4 / 7$ & $9: 45$ & $12: 10$ & $0: 55$ & $5: 20$ \\
\hline Kyusyu & $2012 / 4 / 1$ & $10: 15$ & $12: 10$ & $0: 55$ & $6: 20$ \\
\hline
\end{tabular}

\begin{tabular}{|c|c|c|}
\hline \multirow{3}{*}{ PEFC } & \multirow{2}{*}{$\begin{array}{l}\text { Operation } \\
\text { method }\end{array}$} & $\begin{array}{l}\text { During operation, power generation is performed at the rated output, and surplus electricity is reversely } \\
\text { flown to electric company's public utility supply system. }\end{array}$ \\
\hline & & Power generation follows power demand. \\
\hline & $\begin{array}{l}\text { Stop } \\
\text { condition }\end{array}$ & $\begin{array}{l}\text { Stop power generation under the following conditions. } \\
\text { When the amount of hot water satisfies daily cumulative hot water supply demand, when the hot water storage tank becomes full and the } \\
\text { power generation time reaches } 20 \text { hours. }\end{array}$ \\
\hline \multirow{3}{*}{ SOFC } & \multirow{2}{*}{$\begin{array}{l}\text { Operation } \\
\text { method }\end{array}$} & $\begin{array}{l}\text { During operation, power generation is performed at the rated output, and and surplus electricity is } \\
\text { reversely flown to electric company's public utility supply system. }\end{array}$ \\
\hline & & Power generation follows power demand. \\
\hline & $\begin{array}{l}\text { Operation } \\
\text { condition }\end{array}$ & Continue driving 24 hours a day 365 days. \\
\hline
\end{tabular}

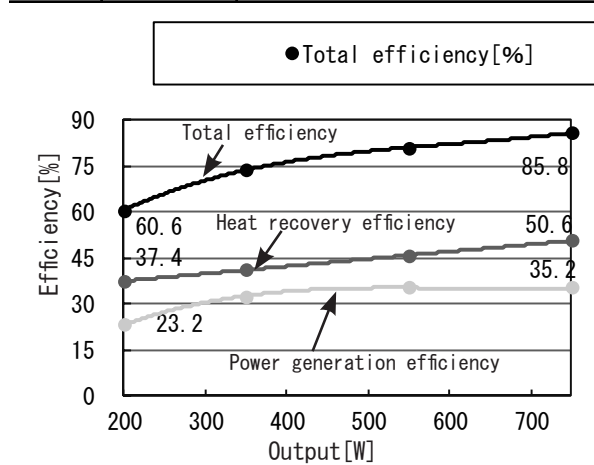

(a) $\operatorname{PEFC}(\mathrm{I}$, II )

- Power generation efficiency [\%]

- Heat recovery efficiency[\%]

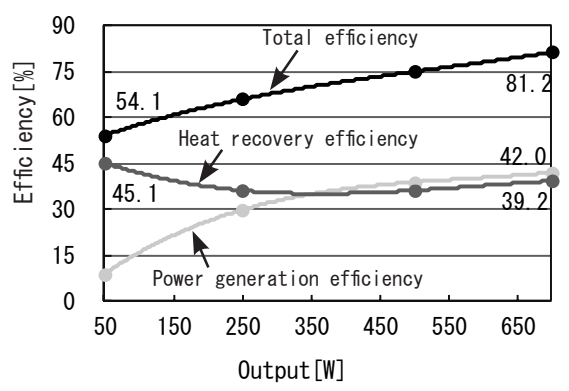

(b) SOFC- I

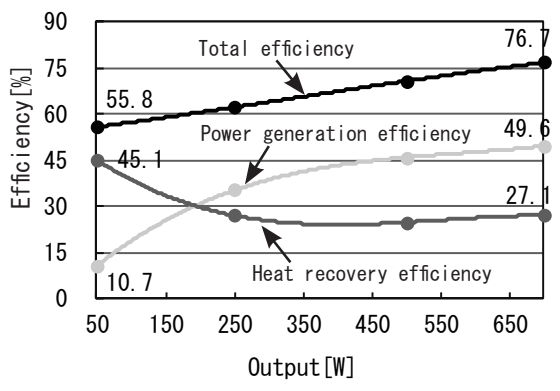

(c) SOFC- II

Fig. 8 Capacity curve of FC at partial load 
燃料電池の運転方法は定格運転及び電主運転とする。定格運転に よる一次エネルギー削減効果との比較を行うため、電主運転による 検討も行う。電主運転時には図 8 の部分負荷時能力曲線を用いて各 効率を変化させる。能力曲線は実際に家庭用 FCCGS を販売している 企業へのヒアリングに基づいて作成した。家庭用 FCCGS 稼働時の余 剩電力は逆潮流させる。尚、本稿では FC 貯湯タンクからの熱損失 は無視している。熱損失を考慮した検討は今後の課題としたい。

\section{5 計算フロー及び計算 case}

表 10 に計算パラメータを、表 11 に計算 case を示す。世帯人員 数 2 パターン×電源構成 2 パターン×燃料電池の設置・仕様 5 パ ターン×燃料電池の運転方法 2 パターン＝計 60 パターンの計算を 行い、本論文では表 11 に示す case について報告する。世帯人員数 2 パターンでは、住宅負荷主 ${ }^{12}$ ( 電力消費スケジュール、給湯スケ ジュール）を、電源構成 2 パターンでは発電構成における原発の有 無 (電力供給量及び時刻別原単位) を、燃料電池の設置・仕様 5 パ ターンでは燃料電池の機種・設置条件をそれぞれパラメータとする。

比較対象住宅 (以下、従来住宅) 及び家庭用 FCCGS 設置住宅 ( 以下、FC 住宅) の住宅種別・仕様、電力消費スケジュール、給 水・給湯データは同様とする。系統電力から買電する際の一次エ ネルギー消費原単位は各時刻の電力供給実績值と図 5 から求めた 供給量別一次エネルギー消費原単位を用いる。給湯は、従来住宅 では高効率ガス給湯器 (熱効率：95[\%])、FC 住宅では家庭用 FCCGS（湯量不足時にはバックアップボイラー（熱効率 95[\% ] ) で 補う) で行うものとする。なお、家庭用 FCCGS の稼働シミュレーショ ンは 5 分刻みで行うが、一次エネルギー消費量の計算では系統電 力の電力供給実績値の公開が 1 時間単位のため、家庭用 FCCGS の 稼働シミュレーション結果を 1 時間単位に積算し、計算を行う。

Table 10 Calculation conditions

\begin{tabular}{|c|c|}
\hline & Calculation parameters \\
\hline \multirow{2}{*}{$\begin{array}{l}\text { Number of household } \\
\text { members }\end{array}$} & (1)Detached house: 3 people, Apartment house: 2 people \\
\hline & (2) Detached house: 4 people, Apartment house: 3 people \\
\hline \multirow{2}{*}{ Year to be analyzed } & (1)2010, before the earthquake, nuclear plants are driving. \\
\hline & (2)2012, after the earthquake, nuclear plants are not driving. \\
\hline \multirow{5}{*}{$\begin{array}{l}\text { Specifications of } \\
\text { Home-use FCGGS and } \\
\text { installation rate }\end{array}$} & $\begin{array}{l}\text { (1)Detached house: SOFC- I (Current specification: 90L) } \\
\text { Apartment house: PEFC- I (City gas: 147L) }\end{array}$ \\
\hline & $\begin{array}{l}\text { (2Detached house: SOFC-II (Future specification: } 30 \mathrm{~L} \text { ) } \\
\text { Apartment house: PEFC- I (City gas: 147L) }\end{array}$ \\
\hline & $\begin{array}{l}\text { 3Detached house: SOFC-II (Future specification: 90L) } \\
\text { Apartment house: PEFC- I (City gas: 147L) }\end{array}$ \\
\hline & $\begin{array}{l}\text { (4) Detached house: PEFC- I (City gas: 147L), PEFC-I (LP gas: 200L). } \\
\text { Installation rate is } 9: 1=\text { PEFC-I : PEFC-II } \\
\text { Apartment house: SOFC-II (Future specification: } 30 \mathrm{~L} \text { ) }\end{array}$ \\
\hline & $\begin{array}{l}\text { 5) Detached house: PEFC- I (City gas: 147L), PEFC-II (LP gas: 200L). } \\
\text { Installation rate is } 9: 1=\text { PEFC-I : PEFC-II } \\
\text { Apartment house: SOFC- I (Current specification: 90L) }\end{array}$ \\
\hline
\end{tabular}

Table 11 Analysis cases

\begin{tabular}{|c|c|c|c|c|c|c|c|}
\hline \multirow{3}{*}{ case } & \multicolumn{2}{|c|}{$\begin{array}{c}\text { Number of } \\
\text { household menbers }\end{array}$} & \multirow{3}{*}{$\begin{array}{c}\text { Year to } \\
\text { be analyzed }\end{array}$} & \multicolumn{4}{|c|}{ Fuel cell conditions } \\
\hline & \multirow[b]{2}{*}{$\begin{array}{c}\text { Detached } \\
\text { house }\end{array}$} & \multirow[b]{2}{*}{$\left|\begin{array}{c}\text { Apartment } \\
\text { house }\end{array}\right|$} & & \multirow[b]{2}{*}{$\begin{array}{l}\text { Operation } \\
\text { method }\end{array}$} & \multicolumn{3}{|c|}{ Installation conditic } \\
\hline & & & & & $\begin{array}{c}\text { Detached } \\
\text { house }\end{array}$ & $\begin{array}{l}\text { Apartment } \\
\text { house }\end{array}$ & $\begin{array}{c}\text { FCCGS } \\
\text { parameters } \\
\text { in table }\end{array}$ \\
\hline case1 & 3 & 2 & \multirow{2}{*}{2012} & \multirow{4}{*}{ Method 1} & \multirow{5}{*}{ SOFC- I } & \multirow{7}{*}{ PEFC- I } & \\
\hline case2 & 4 & 3 & & & & & \\
\hline case3-A & \multirow{7}{*}{3} & \multirow{7}{*}{2} & 2010 (caseA) & & & & (1) \\
\hline case3-B & & & 2010 (caseB) & & & & \\
\hline case4 & & & \multirow{5}{*}{2012} & Method 2 & & & \\
\hline case5 & & & & \multirow{4}{*}{ Method 1} & SOFC- II (30L) & & (2) \\
\hline case6 6 & & & & & SOFC- II (90L) & & (3) \\
\hline case7 & & & & & \multirow{2}{*}{\begin{tabular}{|l|} 
PEFC- I : $: 90 \%$ \\
PEFC- II $: 10 \%)$
\end{tabular}} & SOFC- II (30L) & (4) \\
\hline case8 & & & & & & SOFC- I & (5) \\
\hline
\end{tabular}

家庭用 FCCGS を多数設置した際の導入効果の検討を行う場合、 FC の発電電力により系統電力負担分の電力需要が減少するため、 FC 設置前後において系統電力の一次エネルギー消費原単位が低下 し、従来住宅及び非住宅部門注13) においても一次エネルギー消費 量が削減されると考えられる。その為、本研究では FC 設置住宅 以外の住宅及び非住宅部門も考慮し、FC 導入効果の検討を行う。 各一般電気事業者の電力供給実績值から FC による発電電力の合 計を差し引いた值を系統電力負担分の電力供給量とし、図 5 によ り供給量別一次エネルギー消費原単位を求め、従来住宅及び非住 宅部門における一次エネルギー消費量を算出する。

以上で設定した各種計算条件を基にパラメータスタディを行 い、家庭用 FCCGS 導入前後の一次エネルギー消費量を求め、削減 量を算出する。計算に用いる数式を以下に示す。

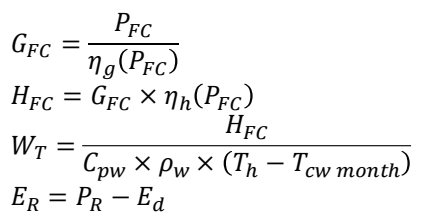

$H_{F C}=G_{F C} \times \eta_{h}\left(P_{F C}\right)$

$E_{R}=P_{R}-E_{d}$

$\cdots(3)$

Operation method: Method1

$P_{F C}=P_{R}$

Operation method: Method2

$P_{F C}= \begin{cases}E_{\mathrm{d}} & \left(E_{\mathrm{d}} \leq P_{R}\right) \\ P_{R} & \left(E_{\mathrm{d}}>P_{R}\right)\end{cases}$

$E_{F C, d}=U_{p}\left(E_{S A}\right) \times\left(E_{p, d}-E_{R, d}\right)+G_{F C, d}+B_{F C, d}$

$E_{F C, a}=U_{p}\left(E_{S A}\right) \times\left(E_{p, a}-E_{R, a}\right)+G_{F C, a}+B_{F C, a}$

$C_{d}=U_{p}\left(E_{S A}\right) \times E_{p, c d}+G_{c d}$

$\cdots(10)$

$C_{a}=U_{p}\left(E_{S A}\right) \times E_{p, c a}+G_{c a}$

$\cdots(11)$

$R_{F c, d}=C_{d}-E_{F C, d}$

$\cdots(12)$

$R_{F c, a}=C_{a}-E_{F C, a}$

$C=\int E_{p, c d} d A+\int E_{p, c a} d A$

$E=E_{S A}-\left(\int E_{g, d} d A+\int E_{g, a} d A\right)$

$N=3600 \times E-\left(\int \mathrm{E}_{p, c d} d A+\int E_{p, c a} d A\right)$

$R_{C}=\left(U_{p}\left(E_{S A}\right)-U_{p}(E)\right) \times C$

$R_{n}=\left(U_{p}\left(E_{S A}\right)-U_{p}(E)\right) \times N$

$R_{\mathrm{A}}=R_{F c, d}+R_{F c, a}+R_{c}+R_{n}$

\section{6 計算結果}

\section{1 家庭用 FCCGS の稼働シミュレーション結果}

図 9 に家庭用 FCCGS の稼働シミュレーション結果 (case6) を示す。 夏季最寒日において集合住宅に設置された PEFC- I は 13 時 00 分に 発電を開始する。その後 5 時間 50 分の稼動を行い、18 時 50 分に当 日の給湯需要量を満たし停止する。SOFC- II（90L）、PEFC- I による 発電電力量は 1 日の消費電力量の内それぞれ $86.5[\%$ ］、15.1 [ \% ] を賄っており、逆潮流電力量は家庭用 FCCGS による発電電力量の内 それぞれ 51.3[\% ]、68.3[\% ] である。又、日平均総合効率はそれ ぞれ $72.3 \% 、 85.8 \%$ である。

\section{2 各住宅における年間一次エネルギー消費量}

図 10 に各住宅における年間の一次エネルギー消費量 (case6) を 示す。電力の一次エネルギー消費量は買電による一次エネルギー 
消費量と逆潮流による一次エネルギー削減量を合算して表す。マ イナスの值の場合は年間を通して買電によって消費した一次エネ ルギーと比較して逆潮流により削減した一次エネルギーが多いこ とを表している。ここでは代表として北海道、宮城、東京、新潟、 大阪、福岡の結果を示す。case6 では各地域の戸建住宅における 正味の年間一次エネルギー消費量は、FC を設置した場合では約 41 ～56[GJ/年・戸 ]、従来住宅では約 $51 \sim 67[\mathrm{GJ} /$ 年・戸 $]$ となり、 FC を設置した場合で約 $11 〜 24[\%$ 減少する。集合住宅におけ る正味の年間一次エネルギー消費量は、FC を設置した場合では約 $41 \sim 50[\mathrm{GJ} /$ 年・戸]、従来住宅では約 $44 \sim 54$ [GJ/年・戸 ] となり、 FC を設置した場合で約 $5 \sim 9[\%]$ 減少する。電力・熱需要とも に比較的多い北海道において削減量が多くなる傾向がある。また、 震災後において系統電力の一次エネルギー消費原単位が比較的多 い東京電力（東京）や関西電力（大阪）管内では逆潮流による一 次エネルギー削減量が多くなる傾向がある。

\section{3 東京電力管内における年間の一次エネルギー削減量}

図 11 に日積算一次エネルギー削減量と日積算供給実績值の年変 化 (case6、東京電力管内) を示す。FC 住宅全体では一次エネルギー 消費量は年間で $12[\mathrm{PJ}]$ 程度削減される。戸建住宅では SOFC- II に より終日定格運転が行われており、貯湯タンク容量を満たした後 の回収熱量はラジェータで大気に放熱されているが、燃料電池の 発電効率が系統電力の受電端発電効率と比較して高いため、熱利 用を行わない状態においても一次エネルギーが削減される。また、 家庭用 FCCGS の導入により対象電力管内全体の電力需要量の系統

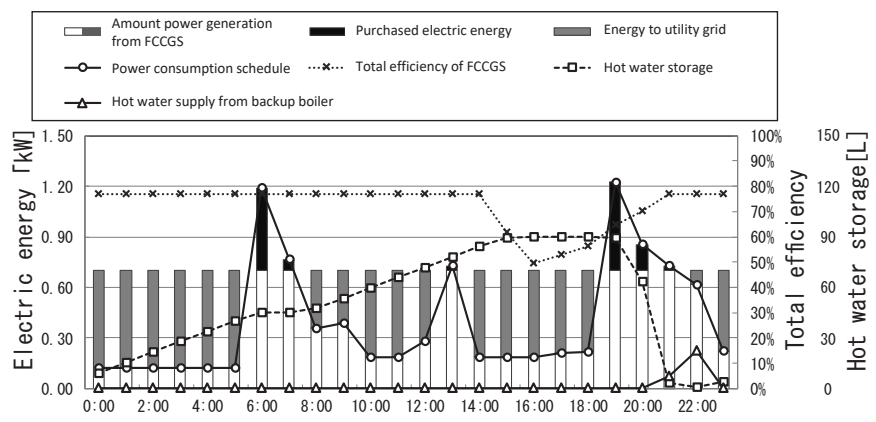

(1) Tokyo, detached houses, 3 people, after the earthquake, SOFC- II $(90[\mathrm{~L}])$, coolest day in summer, rated operation

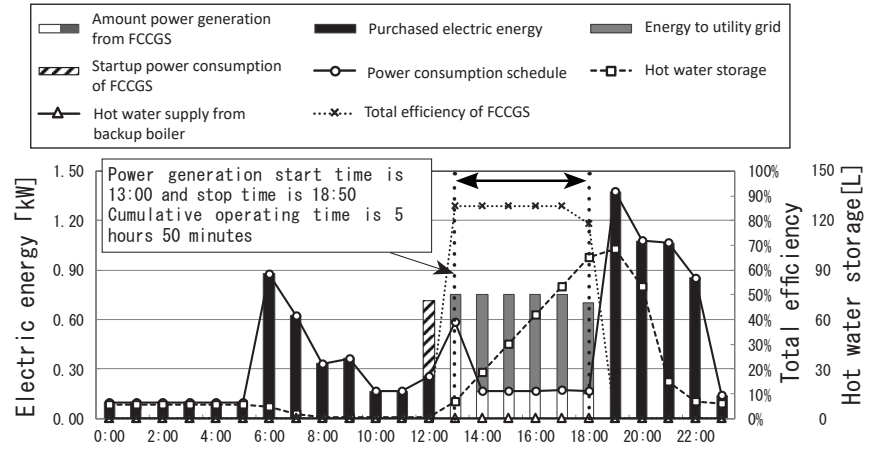

(2) Tokyo, apartment house, 2 people, after the earthquake, PEFC-I, coolest day in summer, rated operation

Fig. 9 Results of operation simulation of home-use FCCGS (case6)
電力負担分が減少し、系統電力の供給量別一次エネルギー消費原 単位が減少する。その為、家庭用 FCCGS の導入前後で同等の電力 需要量である従来住宅及び非住宅部門では、年間を通じて一次エ ネルギー消費量が削減される。東京電力管内での一次エネルギー 消費量は case6 の場合、年間で $23 \mathrm{PJ}$ 程度削減される。

\section{4 全国における一次エネルギー削減量の比較}

図 12 に日本全国における年積算一次エネルギー削減量及び削減率 を示す。各地域での日積算一次エネルギー削減量を合算し、日本全 国の一次エネルギー削減量を算出する。一次エネルギー削減率は一 般電気事業者の火力発電の年間燃料消費量 ${ }^{30)}$ に各ガス会社の都市ガ スと LPガスの年間販売量 ${ }^{12)}$ を加えて算出する (2010年度 : $5,643[\mathrm{PJ}]$ 、 2012 年度 : 6, 093 [PJ])。今回の検討 case では、case6 の場合で最も 一次エネルギー削減量が多く、日本全国での一次エネルギー消費量 は約 75[PJ] 削減され、一次エネルギー削減率は 1.3[\% ] となる。

各 case の比較を行うと、世帯人員数 (case1、case2) では、 $\operatorname{case} 2$ ( 戸建 : 4 人、集合：3人) の方が、給湯の需要が相対的に多い 為、FC 住宅における一次エネルギー削減量が多く、総一次エネルギー 削減量も約 $25[\%$ ］多くなる。電源構成 (case1、case3) で比較すると、 どちらの場合でも総一次エネルギー消費量は削減されるが、case 3 (原 発あり (2010 年度 )) では FC 住宅の一次エネルギー消費量は増加して いる。原発を含めた発電構成の場合、系統電力の一次エネルギー消費 原単位が相対的に小さい為、一次エネルギー削減量は少なくなる。燃 料電池の運転方法 (case1、case4) で比較すると、逆潮流分の発電電 力があるため、定格運転を行った case 1 の方が一次エネルギー削減量

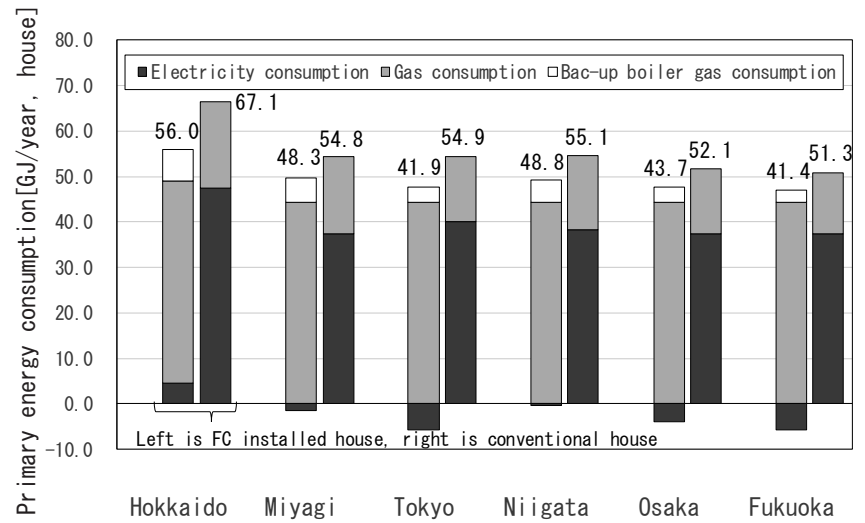

(1) Detached house, 3 people, after the earthquake, SOFC- II $(90[\mathrm{~L}])$

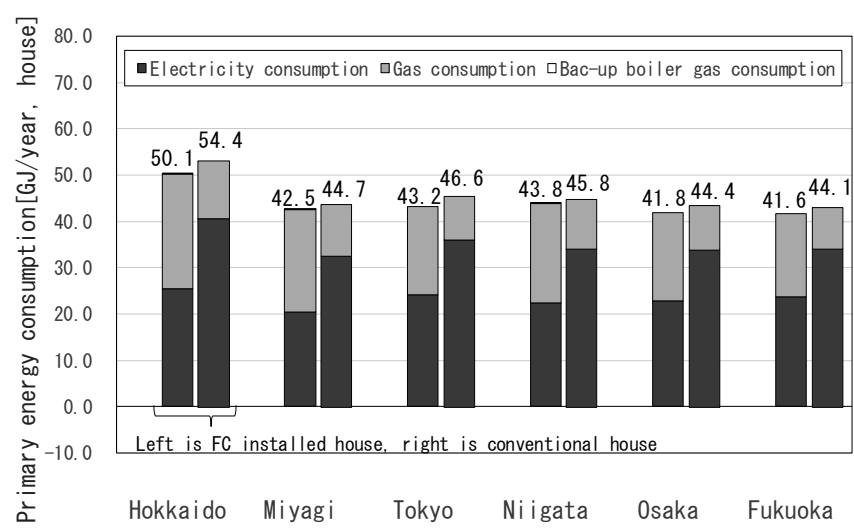

(2) Apartment house, 2 people, after the earthquake, PEFC-I

Fig. 10 Results of annual primary energy consumption in a house (case6) 
は約 40[\% ] 多い傾向がある。SOFC の仕様（case1、case5）を比較す ると、case5 の方が将来仕様で発電効率が高い為、総一次エネルギー 削減量が約 20[\% ] 多くなる。SOFCの貯湯タンク容量 (case5 : 30 [L]、 case6 : 90[L]）で比較すると、case6 の方が貯湯タンク容量が大きく、 大気に放熱されるエネルギーが少なくなる為、FC 住宅における一次 エネルギー削減量が多く、総一次エネルギー削減量は約 $23[\%]$ 多く なる。燃料電池の設置条件 (case1 と case8 及び case5 と case7 では、 総一次エネルギー削減量に大きな差は見られない。

一次エネルギー削減率は、原発なし（震災後：2012 年度）の case では $0.6 \sim 1.3[\%$ 程度となり、原発あり（震災前 $: 2010$ 年 度 ）では case3-A では約 0.1[\% ] 、case3-B では約 0.8[\% ] となる。 分散型電源として燃料電池を多数導入し、逆潮流を含めた稼働を 行うことは我が国の一次エネルギー消費量の削減に対して一定の 効果があると考えられる。

また、各 case の一次エネルギー削減量の内訳では、系統電力の電 力負担が減少し、一次エネルギー消費原単位が低下寸ることによっ て生じる非住宅部門の一次エネルギー削減量が相対的に大きく、ど の case でも約 6 割以上を占める。分散型電源を多数導入する場合の

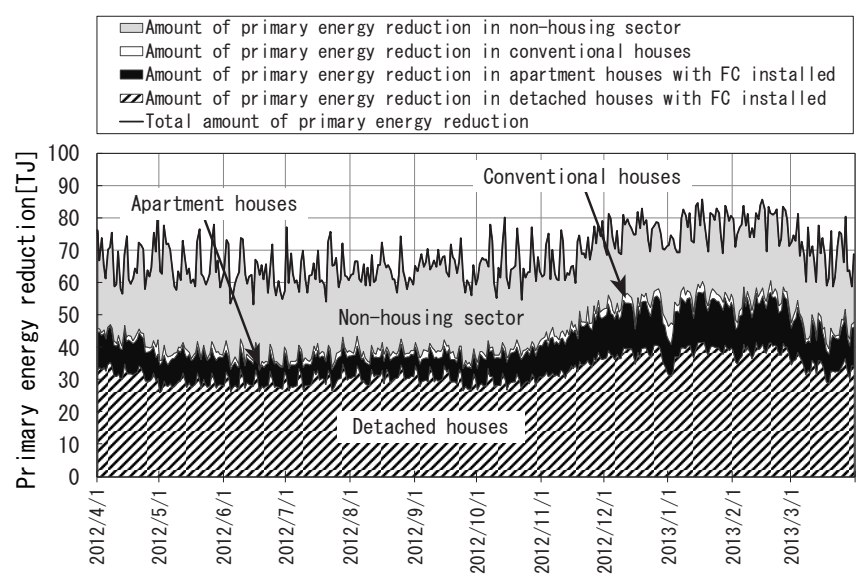

Fig. 11 Energy reduction amount and power supply amount in TEPCO (case 6, detached house: 3 people, SOFC- II $(90[\mathrm{~L}])$, apartment house: 2 people, PEFC-I, rated operation, after the earthquake, 2012)

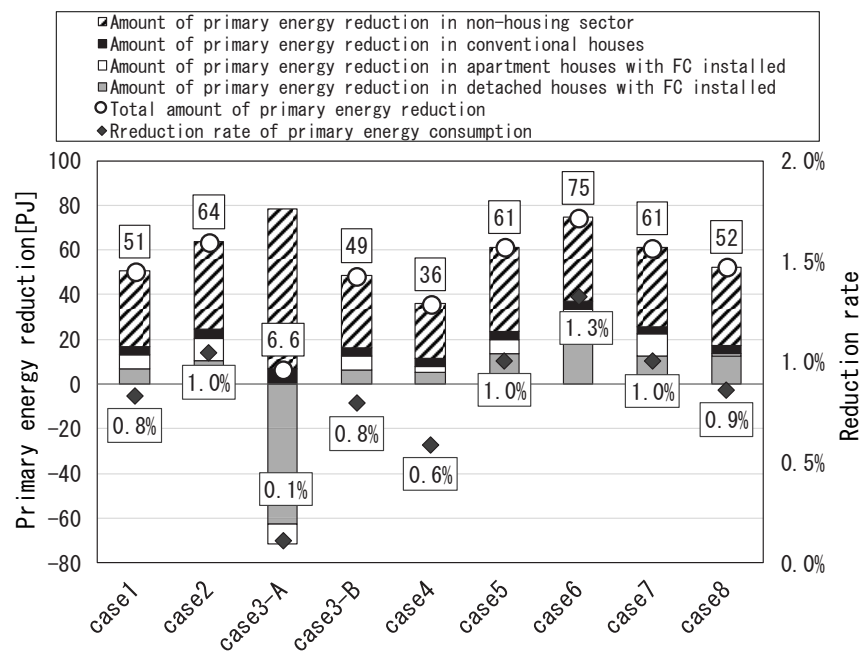

Fig. 12 Yearly cumulative primary energy reduction and reduction rate in Japan
省エネルギー効果を評価する際には、系統電力の電力負担の変化に よる影響を考慮することは極めて重要であると考えられる。

\section{7 まとめ}

本研究では、一般電気事業者の発電構成・電力供給量を対象と して、日本全国で SOFC 及び PEFC を計 530 万台稼働させた場合の 数值シミュレーションを行い、逆潮流によって系統電力の一次エ ネルギー消費原単位が減少することによる一次エネルギー消費量 の削減効果を含めた家庭用 FCCGS の分散型電源としての導入効果 の評価を行った。本研究で得られた知見は以下の通りである。

本研究では電主運転 (逆潮流なし) と比較して定格運転（逆潮 流あり）を行った場合で一次エネルギー削減量は約 4 割多くなる。 定格運転では貯湯タンクが満蓄となった場合、燃料電池からの排 熱は大気へ放出されるが、燃料電池の発電効率が系統電力の発電 効率と比較して高いため、逆潮流により一次エネルギー削減効果 が得られたと考えられる。

家庭用燃料電池を導入する場合、今回の解析条件では世帯人員 数の多い方が、一次エネルギー削減量は多くなる。これは世帯人 員数が多い場合、給湯需要が相対的に多くなるため、燃料電池の 総合効率が高くなるためと考えられる。

同一の燃料電池の仕様では、貯湯タンク容量が大きい方が、大気 に放熱されるエネルギーが少なくなる為、一次エネルギー削減量が 多くなる。PEFC と比較して発電効率が高く、排熱の少ないSOFCでは、 機器の設置スペースも考慮し、貯湯タンク容量が比較的少なく設計 されているが、省エネルギーのためには排熱の有効利用を考慮して 最適な貯湯タンク容量を決定することが重要であると考えられる。

一次エネルギー削減率は、原発なし（2012 年度）の場合、0.6〜 $1.3[\%]$ 程度となり、原発あり（2010 年度）では約 $0.1 \sim 0.8[\%]$ となる。系統電力の電源構成に原発が存在している場合、系統電 力の一次エネルギー消費原単位が原発なしの場合と比較して小さ いため、一次エネルギー削減量は相対的に小さくなる傾向がある。 本研究で検討したどの case でも燃料電池を導入することにより、 一次エネルギー削減効果は得られた。我が国において住宅に家庭 用燃料電池を多数導入し、逆潮流を含めた稼働を行うことは一次 エネルギー消費量の削減に対して一定の効果があると考えられる。

分散型電源を多数導入する場合、系統電力側が負担する電力需 要の変化に伴い、系統電力の一次エネルギー消費原単位も当然変 化すると考えられる。本研究では従来住宅部門、非住宅部門にお ける一次エネルギー削減効果の検討も行ったが、系統電力の一次 エネルギー消費原単位の低下によって生じる非住宅部門での一次 エネルギー削減量は相対的に大きいことが明らかとなった。分散 型電源を多数導入する際の省エネルギー効果を評価する場合、系 統電力の電力負担の変化による影響を考慮することは、極めて重 要であると考えられる。

\section{記号}

$\mathrm{T}_{\mathrm{cw} \text { monh }}$ : Monthly average feedwater water temprature $\left[{ }^{\circ} \mathrm{C}\right]$

$\mathrm{T}_{\text {air month }}$ : Monthly average outdoor temprature $\left[{ }^{\circ} \mathrm{C}\right]$

a: Regression coefficient

$\mathrm{b}$ : Regression coefficient

$\mathrm{P}_{\mathrm{FC}}:$ Power generation of FC $[\mathrm{kW}]$

$\mathrm{H}_{\mathrm{FC}}$ : Heating output of $\mathrm{FC}[\mathrm{kW}]$ 
$\eta_{\mathrm{g}}\left(\mathrm{P}_{\mathrm{FC}}\right)$ : Power generation efficiency of FC $[\%]$

$\eta_{\mathrm{h}}\left(\mathrm{P}_{\mathrm{FC}}\right)$ : Heat recovery efficiency of FC $[\%]$

$\mathrm{P}_{\mathrm{R}}$ : Rating capability of $\mathrm{FC}$ power generation $[\mathrm{kW}]$

$E_{\mathrm{d}}$ : Electricity demand of house $[\mathrm{kW}]$

$\mathrm{W}_{\mathrm{s}}$ : Supply amount of hot water $\left[\mathrm{m}^{3}\right]$

$\rho_{\mathrm{w}}:$ Density of water $\left[\mathrm{kg} / \mathrm{m}^{3}\right]\left(1,000\left[\mathrm{~kg} / \mathrm{m}^{3}\right]\right)$

$\mathrm{C}_{\mathrm{pw}}$ : Specific heat of water $[\mathrm{J} /(\mathrm{g} \cdot \mathrm{K})](4.2[\mathrm{~J} /(\mathrm{g} \cdot \mathrm{K})])$

$\mathrm{T}_{\mathrm{h}}$ : Hot water storage temperature $\left[{ }^{\circ} \mathrm{C}\right]\left(70\left[{ }^{\circ} \mathrm{C}\right]\right)$

$\mathrm{E}_{\mathrm{FC}, \mathrm{d}}$ : Primary energy consumption in detached house with FC [MJ]

$\mathrm{E}_{\mathrm{FC}, \mathrm{a}}$ : Primary energy consumption in apartment house with FC [MJ]

$\mathrm{E}_{\mathrm{p}, \mathrm{d}}:$ Purchased electric energy in detached house with $\mathrm{FC}[\mathrm{kWh}]$

$\mathrm{E}_{\mathrm{p}, \mathrm{a}}$ : Purchased electric energy in apartment house with $\mathrm{FC}[\mathrm{kWh}]$

$\mathrm{E}_{\mathrm{R}, \mathrm{d}}:$ Reverse power flow in detached house with $\mathrm{FC}[\mathrm{kWh}]$

$\mathrm{E}_{\mathrm{R}, \mathrm{a}}$ : Reverse power flow in apartment house with $\mathrm{FC}[\mathrm{kWh}]$

$\mathrm{G}_{\mathrm{FC}, \mathrm{d}}$ : Gas consumption in detached house with FC [MJ]

$\mathrm{G}_{\mathrm{FC}, \mathrm{a}}$ : Gas consumption in apartment house with $\mathrm{FC}[\mathrm{MJ}]$

$\mathrm{B}_{\mathrm{FC}, \mathrm{d}}$ : Back-up boiler gas consumption in detached house with $\mathrm{FC}[\mathrm{MJ}]$

$\mathrm{B}_{\mathrm{FC}, \mathrm{a}}$ : Back-up boiler gas consumption in apartment house with $\mathrm{FC}[\mathrm{MJ}]$

$\mathrm{U}_{\mathrm{p}}(\mathrm{p})$ : Receiving end primary energy consumption unit $[\mathrm{MJ} / \mathrm{kWh}]$

$\mathrm{p}$ : Power supply amount of general electric utility $[\mathrm{kW}]$

$\mathrm{C}_{\mathrm{d}}$ : Primary energy consumption in conventional detached house [MJ]

$\mathrm{E}_{\mathrm{p}, \mathrm{dd}}:$ Purchased electric energy in conventional detached house [kWh]

$\mathrm{G}_{\mathrm{cd}}$ : Gas consumption in conventional detached house [M]

$\mathrm{C}_{\mathrm{a}}$ : Primary energy consumption in conventional apartment house [M]

$\mathrm{E}_{\mathrm{p}, \mathrm{ca}}$ : Purchased electric energy in conventional apartment house $[\mathrm{kWh}]$

$\mathrm{G}_{\mathrm{ca}}$ : Gas consumption in conventional apartment house [MJ]

$\mathrm{R}_{\mathrm{FC}, \mathrm{d}}$ : Amount of primary energy reduction in detached house with $\mathrm{FC}[\mathrm{MJ}]$

$\mathrm{R}_{\mathrm{FC}, \mathrm{a}}$ : Amount of primary energy reduction in apartment house with $\mathrm{FC}[\mathrm{MJ}]$

$\mathrm{N}$ : Electric energy consumption in non-housing sector $[\mathrm{kWh}]$

$\mathrm{E}_{\mathrm{SA}}$ : Electricity supply amount $[\mathrm{kW}]$

$\mathrm{E}_{\mathrm{g}, \mathrm{d}}$ : Electric generation of $\mathrm{FC}$ in detached house $[\mathrm{kW}]$

$\mathrm{E}_{\mathrm{g}, \mathrm{a}}:$ Electric generation of $\mathrm{FC}$ in apartment house $[\mathrm{kW}]$

$\mathrm{E}$ : Electricity supply amount after reduction of electric energy demand in FC houses $[\mathrm{kW}]$

$\mathrm{C}$ : Electric energy demand in conventional houses $[\mathrm{kWh}]$

$\mathrm{R}_{\mathrm{c}}$ : Amount of primary energy reduction in conventional houses [MJ]

$\mathrm{R}_{\mathrm{n}}$ : Amount of primary energy reduction in non-housing sector [MJ]

$\mathrm{R}_{\mathrm{A}}$ : Total amount of primary energy reduction in each area [M]

A:Area of each 9 general electric utility

$\mathrm{P}_{\text {shikoku }}$ : Hourly Power supply amount in Shikoku Electric Power Co.,Inc. $\left[10^{4} \mathrm{kWh}\right]$

$\mathrm{P}_{\text {Chugoku }}$ :Hourly Power supply amount in Chugoku Electric Power Co.,Inc. $\left[10^{4} \mathrm{kWh}\right]$

\section{注}

注 1）逆潮流とは自家発電により発電した余剩電力を系統電力側に逆流させるを 言う。現状では、家庭用 FCCGS の余剩電力は系統連系規定により逆潮流出来ない。 注 2）エネルギー基本計画における家庭用燃料電池の 2030 年の普及目標台数。

注 3） 本研究では電力の一次エネルギー消費量の算出には「エネルギー使用の合 理化等に関寸る法律」(以下、省エネ法) で規定されている電力の一次エネル ギー消費原単位である 9.97[MJ/kWh] (昼間)、9.28[MJ/kWh] (夜間 ) は用いず、本 研究で新たに算出する供給量別一次エネルギー消費原単位を用いる。これは家 庭用 FCCGS が発電する時刻に応じて一次エネルギーの削減効果が異なると考え られることと、本研究の特徴の一つである系統電力の電力負担の減少による一 次エネルギー消費原単位の低下を考慮するためである。

注 4）静岡県は富士川以東を東京電力が、富士川以西を中部電力がそれぞれ供給 管轄地域としているため、代表都市は富士川以東の市町村で世帯数、世帯人員数と もに最大 ${ }^{14)}$ である富士市、富士川以西については県庁所在地である静岡市とする。

注 5）本研究では全国における住宅の断熱性能は統一して設定しており、断熱性能 を省エネルギー基準における地域区分等に応じて変化させた場合の一次エネル ギー削減量を検討することは今後の課題としたい。なお、本研究では、各都道府 県において人口が集中していると考えられる都道府県庁所在地を対象にシミュ レーションを行うが、省エネルギー基準における地域区分において本研究で設 定した断熱性能を上回る值が設定されている $1 \sim 4$ 地域に該当するのは、北海道 札幌市 (地域 2)、青森県青森市 (地域 4)、岩手県盛岡市 (地域 3)、秋田県秋田 市 (地域 4)、宮城県仙台市 (地域 4)、山形県山形市 (地域 4)、福島県福島市 (地 域 4)、長野県長野市（地域 4) である。全国の世帯数に対するこれらの地域の世 帯数の割合は合計で約 1 割であり、断熱性能を省エネルギー基準における地域区 分に則って設定することによる全国における一次エネルギー削減量への影響は相 対的に小さいと考えられる。また、省エネルギー基準における地域区分に則った
断熱性能とした場合、現状の断熱性能の熱負荷計算と比較して空調負荷が減少 すると考えられ、空調用電力消費量が少なくなるため、FC 住宅では燃料電池の 発電電力によって賄うことができる電力需要の割合が増加し、買電電力量が減少 すると考えられる。また定格運転時では逆潮流電力量が増加寸ると考えられるた め、本論文の解析結果と比較して一次エネルギー削減量は増加すると考えられる。 注 6) 本研究で対象としている 2010 年、2012 年における各世帯の構成割合 ${ }^{311}$ は、 1 人世帯: 約 $25 \% 、 2$ 人世帯: 約 $30 \% 、 3$ 人世帯: 約 $20 \%$ 、4 人世帯: 約 $16 \% 、 5$ 人世帯: 約 6\%、6 人以上の世帯: 約 3\%である。本研究で対象とした家庭用 FCOGS では 人世帯の住宅において、一戸に一台を設置することは考えにくいため、世帯構成 割合が多く、家庭用 FCOGS の設置が考えられる 2 人世帯、3 人世帯、4 人世帯の住 宅を計算対象とした。また戸建住宅には比較的多人数が居住し、集合住宅には比 較的少人数が居住すると考え、戸建住宅: 3 人、集合住宅: 2 人、または、戸建住宅: 4 人、集合住宅 $: 3$ 人と設定している。1 1 世帯において 2 世帯で 1 つの家庭用燃 料電池を使用するなどの方法も考えられるが、この点は今後検討したい。

注 7）家庭用エアコンの年平均 COP は設置される住宅の地域や断熱性能によって 変化する。既往の研究によると、本研究の住宅モデルと概ね同様の断熱性能を 持つ住宅では、全国的に COP は $2.5 \sim 3.0$ 程度であるため、本研究のシミュレー ションではエアコンのCOP は 3.0 と仮定した。

注 8）四国電力の電力供給量は中国電力の電力供給実績値を用いて以下の回帰式 により推定した。回帰式はデータが得られた期間 (2012 年 7 月〜 2014 年 12 月) における中国電力と四国電力の相関により求めた。

$$
\mathrm{P}_{\text {shikoku }}=0.496 \mathrm{P}_{\text {chugoku }}+17.433 \quad \cdots(20)
$$

注 9）原子力発電の一次エネルギー消費原単位には様々な見積もり方が存在して いるが、本研究では発電時に化石燃料を使用しないことから $0[\mathrm{MJ} / \mathrm{kWh}]$ とする 場合 (caseA) と、国際エネルギー機関 (International Energy Agency:IEA) の算出 方法を参考に、原子力発電の発電効率を国内の火力発電平均効率 $\left(42 \%{ }^{32}\right)$ と同 等と考え、原発の発電端一次エネルギー消費原単位を $8.57[\mathrm{MJ} / \mathrm{kWh}]$ とする場合 (caseB) で検討を行い、解析結果を併記する。

注 10）時刻別一次エネルギー消費原単位の年平均值は、各時刻における時刻別一 次エネルギー消費原単位をその時刻における電力供給実績值により加重平均 して算出する。

注 11）本研究での PEFCの起動時刻は、給湯スケジュールにおいてピークとなる $20: 45$ の給湯需要を最大限満たすように逆算して決定している。実際の PEFC では、学習機能が付属していることが想定され、各家庭で需要に合わせて運転 時間が変化すると考えられる。また PEFC の起動時間について、参考文献 1) に よると PEFCの起動時間は、季節と停止後の放置時間によって変化し、約 40 〜 70 分となっている。筆者らが PEFC の販売元へ行ったヒアリングでは 50 分との 回答を得ており、本研究では PEFC の起動時間は年間を通して一定の 50 分とし ている。起動時間を変化させた場合の検討は今後の課題としたい。

注 12） 本研究では住宅の生活スケジュール（電力消費、給湯需要）は全ての住 宅で同一としている。本来は生活スケジュールがばらつくため、系統電力の負 荷が平準化されると考えられる。なお、case 1 を対象として、住宅を $1 / 3$ ずつの グループに分け、生活スケジュールを 1 時間早めるグループ、現状とするグルー プ、1 時間遅らせるグループを作成して計算を行ったが、最終的な一次エネル ギー削減量は殆ど変化しないことを確認している。

注 13） 1 世帯当たりの電力消費量及び世帯数から、エリア全体での家庭部門の電 力消費量を算出し、各電力会社の電力供給実績值から家庭部門の電力消費量を 差し引いた残りを非住宅部門の電力消費量とする。

\section{参考文献}

1) Kuroki H., Shimizu S., Takaguchi H., Watanabe T. :Effective Operation Methods and Energy Conservation Effect of Housing Polymer Electrolyte Fuel Cell Cogeneration Systems Installation Effect of Distributed Power and Heat Source System for Housing (Part 1), Journal of Environmental Engineering (Transactions of AIJ), No.610, pp. 67-73, 2006.12 (in Japanese)

2) Kuroki H., Shimizu S., Nakao M., Aoki H., Takaguchi H., Watanabe T. :Study on Energy Conservation Effects of Housing Electricity and Heat Source Equipments Installation Effect of Distributed Power and Heat Source System for Housing (Part 2) , Journal of Environmental Engineering (Transactions of AIJ), No.647, pp. 4350, 2010.1 (in Japanese)

3) Sumiyoshi D., Okuda Y., Akashi Y., Ozaki A., Watanabe T. :The Examination for Suitable Spaec of Solid Oxide Fuel Cell Co-generation System and The Proposal of Tank Minimization by Using Bas-tab in Collective Housing, Journal of Environmental Engineering (Transactions of AIJ), Vol. 80 No.711, pp. 441-450, 2015. 5 (in Japanese)

4) Yuasa K., Yata M., Niino S., Park S. :Evaluation on SOFC-CGS Installation 
with Considaration to Electricity and Hot Water Demand Variation Application of Congeneration System in Apartment Building Part 1, Journal of Environmental Engineering (Transactions of AIJ), Vol. 80 No.712, pp.543-550, 2015.6 (in Japanese)

5) Akabayashi S., Sakaguchi J., Oshima T., Ichikawa H. Arinami Y. :Peak Electricity Demand Reduction by Installation of Fuel Cell Cogeneration System in residences Part 1 Results of Simulations for the District of Tohoku Electric Power Company, Journal of Environmental Engineering (Transactions of AIJ), Vol. 78 No. 690, pp. 639-644, 2013.8 (in Japanese)

6) Agency for Natural Resources and Energy: Japan's energy plan http://www. enecho. meti. go. jp/category/others/basic_plan/ [Accessed 2018.9.16]

資源エネルギー庁：エネルギー基本計画

7) Akabayashi S., Sakaguchi J., Arinami Y., Koike H. :Reduction Effect of Primary Energy by Fuel Cell Cogeneration System in Residences Part 1 Analysis Hourly Primary Energy and $\mathrm{CO}_{2}$ ConversionValues of General Electric Utility, Summaries of Technical Papers of Annual Meeting, D-2, Architectural Institute of Japan, D-2, pp. 725-726, 2014.9 (in Japanese)

赤林伸一, 坂口淳, 有波裕貴, 小池洋 : 家庭用燃料電池による一次エネルギー 削減効果に関する研究 その 1 一般電気事業者を対象とした一次エネルギー及 び $\mathrm{CO}_{2}$ の時刻別原単位に関する解析, 日本建築学会大会学術講演梗概集, D-2, pp. 725-726, 2014.9

8) Koike H., Akabayashi S., Sakaguchi J., Arinami Y. :Reduction Effect of Primary Energy by Fuel Cell Cogeneration System in Residences Part 2 Reduction Effect of Primary Energy and $\mathrm{CO2}$ in Kansai area, Summaries of Technical Papers of Annual Meeting, Architectural Institute of Japan, D-2, pp.727-728, 2014.9 (in Japanese)

小池洋, 赤林伸一, 坂口淳, 有波裕貴 : 家庭用燃料電池による一次エネルギー 削減効果に関する研究 その 2 関西エリアを対象とした一次エネルギー及び $\mathrm{CO}_{2}$ 削減効果, 日本建築学会大会学術講演梗概集, D-2, pp. 727-728, 2014.9

9) Sato K., Akabayashi S., Sakaguchi J., Arinami Y. :Reduction Effect of Primary Energy by Fuel Cell Cogeneration System in Residences Part 3 Operation Simulation Result of Fuel Cell Cogeneration System in each house, Summaries of Technical Papers of Annual Meeting, Architectural Institute of Japan, D-2, pp. 853-854, 2015.9 (in Japanese)

佐藤広基, 赤林伸一, 坂口淳, 有波裕貴 : 家庭用燃料電池による一次エネルギー 削減効果に関寸る研究 その 3 各家庭における家庭用燃料電池の稼働シミュ レーション結果, 日本建築学会大会学術講演梗概集, D-2, pp. 853-854, 2015.9

10) Akabayashi S., Sakaguchi J., Arinami Y., Sato K. :Reduction Effect of Primary Energy by Fuel Cell Cogeneration System in Residences Part 4 Reduction Effect of Primary Energy in Japan, Sunmaries of Technical Papers of Annual Meeting, Architectural Institute of Japan, D-2, pp. 855-856, 2015.9 (in Japanese) 赤林伸一, 坂口淳, 有波裕貴, 佐藤広基 : 家庭用燃料電池による一次エネルギー 削減効果に関する研究 その 4 全国を対象とした一次エネルギー削減効果の解 析結果, 日本建築学会大会学術講演梗概集, D-2, pp. 855-856, 2015.9

11) Mitsuhiro U. :Proposal of standard problem, residential standard problem, The Architectural Institute of Japan The 15th Symposium Text on Thermal Working Group of Committee on Environmental Engineering, 1985 (in Japanese)

宇田川光弘 : 標準問題の提案 住宅用標準問題, 日本建築学会環境工学委員会 熱分科会第 15 回シンポジウムテキスト, 1985

12) Gas Business Handbook, 2013 (in Japanese) ガス事業便覧 : 平成 25 年度版

13) Statistics Bureau, Ministry of Internal Affairs and Communications:Census 2010, http://www. stat. go. jp/data/kokusei/2010/ [WEB] [Accessed 2018.9. 16] 総務省統計局 : 平成 22 年国勢調査

14) The Society of heating, air-conditioning and sanitary engineers of Japan, 空気調和衛生工学会 : 住宅消費エネルギー計算法委員会

15) Japan Meteorological Agency:http://www. jma. go. jp/jma/index. html [WEB] [Accessed 2018.9.16]
気象庁 : http://www. jma. go. jp/jma/index. html

16) Wen. X, Akabayashi S., Sakaguchi J., Arinami Y. :Study on accuracy verification of annual performance factor in catalogue for home-use air conditioner by cop measurement experiments, Journal of Environmental Engineering (Transactions of AIJ), Vol. 82, No. 740, pp. 873-882, 2017.10 (in Japanese)

17) Mae M., Takasu N., Nabeshima M., Ichikawa N., Iio A., Kamata M. :Daily and Seasonal Fluctuation of Residential Hot Water Consumption, Journal of Environmental Engineering (Transactions of AIJ), No.622, pp.73-80, 2007.12 (in Japanese)

18) Institute for Building Environment and Energy Conservation: Standards of Judgment for Residential Construction Clients, http://ees. ibec. or. jp/, [WEB] [Accessed 2018.9.16]

建築環境・省エネルギー機構 : 住宅事業建築主の判断基準

19) Institute for Building Environment and Energy Conservation: Energy saving standards and calculations guidelines for buildings Performance standards for new construction and remodeling (PAL / CEC), 2006.9

建築環境・省エネルギー機構 : 建築物の省エネルギー基準と計算の手引 新築・ 増改築の性能基準 (PAL/CEC), 2006.9

20) Hokkaido Electric Power Co., Inc., Homepage :http://www. hepco. co. jp/, [WEB] [Accessed 2018.9.16]

北海道電力 ホームページ

21) Tohoku Electric Power Co., Inc., Homepage :http://www. tohoku-epco. co. jp/, [WEB] [Accessed 2018. 9. 16] 東北電力 ホームページ

22) Tokyo Electric Power Company Holdings, Incorporated, Homepage :http://www. tepco. co. jp/, [WEB] [Accessed 2018.9.16]

東京電力 ホームページ

23) Chubu Electric Power Co., Inc., Homepage :http://www. chuden. co.jp/, [WEB] [Accessed 2018.9.16] 中部電力 ホームページ

24) Hokuriku Electric Power Company, Homrpagre :http://www. rikuden. co.jp/, [WEB] [Accessed 2018.9.16] 北陸電力 ホームページ

25) The Kansai Electric Power Company, Incorporated, Homepage :http://www. kepco. co. jp/, [WEB] [Accessed 2018.9. 16]

関西電力 ホームページ

26) The Chugoku Electric Power Co., Inc., Homepage :http://www. energia. co. jp/, [WEB] [Accessed 2018.9. 16] 中国電力 ホームページ

27) Shikoku Electric Power Company, Incorporated, Homepage :http://www. yonden. co. jp/, [WEB] [Accessed 2018.9. 16]

四国電力 ホームページ

28) Kyushu Electric Power Co., Inc., Homepage :http://www. kyuden. co. jp/, [WEB] [Accessed 2018.9.16] 九州電力 ホームページ

29) Electric Power Civil Engineering Association: http://www. jepoc. or. jp/hydro/ [WEB] (in Japanese) [Accessed 2018.9.9] 一般財団法人電力土木技術協会 : 水力発電所データベース

30) The Federation of Electric Power Companies of Japan: http://www5. fepc. or. jp/ tok-bin/kensaku. cgi [WEB] (in Japanese) [Accessed 2018.9.9] 電気事業連合会 電力統計情報 : 燃料実績

31) Ministry of Health, Labour and Welfare, Comprehensive Survey of Living Conditions, https://www. mhlw. go. jp/toukei/list/20-21.html, [WEB] [Accessed 2019. 2. 10]

厚生労働省, 国民生活基礎調査

32) Tatistics Committee of The Federation of Ten Electric Power Companies; Japan Electric Association, pp. 100-101, 2016. 12

電気事業連合会統計委員会 : 平成 28 年版電気事業便覧, pp. 100-101, 日本電気教 会, 2016. 12 


\title{
STUDY ON PRIMARY ENERGY REDUCTION EFFECT \\ BY INSTALLING HOME-USE FUEL CELL COGENERATION SYSTEM
}

\author{
Yuki ARINAMI ${ }^{* 1}$, Jun SAKAGUCHI*2 and Shin-ichi AKABAYASHI*3 \\ ${ }^{* 1}$ Assist. Prof., Architecture Program, Faculty of Eng., Niigata University, Dr.Eng. \\ ${ }^{* 2}$ Prof., Faculty of International Studies and Regional Development, Dept. of International Studies and Regional Development, \\ University of Niigata Prefecture, Dr.Eng: \\ ${ }^{*}$ Prof., Graduate School of Science and Technology, Niigata University, Dr.Eng.
}

\section{INTRODUCTION}

In this paper, numerical simulation is conducted when total 5.3 million units of Solid Oxide Fuel Cell (SOFC) and Polymer Electrolyte Fuel Cell (PEFC) are installed and operated nationwide, for power generation configuration and electricity supply amount of general electric utilities before and after the Great East Japan Earthquake. Calculate the primary energy reduction amount when a large number of home-use fuel cell co-generation systems (FCCGS) are installed and operated. Evaluation of introduction effect of home-use FCCGS as distributed power supply is performed. When a large number of fuel cells are installed, the power burden of the grid power is reduced. Operation of relatively inefficient power generation facilities will be reduced, and the primary energy consumption unit of grid power will also decrease. There is a possibility that primary energy will be reduced also in the non-residential housing that introduced home-use FCCGS. We will also consider this point in this paper. It is considered important to examine the primary energy reduction amount when introducing a large number of fuel cells in considering Japan's future energy mix.

\section{RESEARCH METHODS}

The target area is 9 areas for each electric power supply range of nine general electric power companies in Japan, and each detached house and apartment house is the target housing. For the housing model of detached houses, use the standard problem model for housing of Architectural Institute of Japan, and for apartment houses, use the intermediate floor / intermediate dwelling model of one corridor type plate type. The average U-value $0.82 \mathrm{~W} /\left(\mathrm{m}^{2} \cdot \mathrm{K}\right)$ for detached houses and $0.68 \mathrm{~W} /\left(\mathrm{m}^{2} \cdot \mathrm{K}\right)$ for apartment houses throughout the country.

For thermal load calculation, use thermal load simulation software TRNSYS Ver.16. Calculate the hourly air conditioning load of each target housing in each prefecture. For meteorological data, weather data for every hour published by the Japan Meteorological Agency on the web, lighting and various pieces of equipment heating data are calculated using SCHEDULE data. Weather data is used for 2010 and 2012.

Type of the cell stack of the fuel cell is two kinds of the polymer electrolyte (PE) and solid oxide (SO). PEFC sets startup time for target area, season, and house type and operation method in order to start and stop once a day. The start-up time is determined as the representative day from the coolest day in winter, summer season, and moderate seasons. In the SOFC installed house, the surplus heat after filling the hot water storage tank capacity is released to the atmosphere with a radiator (fan electric consumption: 4.8W). Surplus electric power during home-use FCCGS operation is flown to utility grid. When power generation of FCCGS follows power demand, each efficiency is changed by using the performance curve at partial load.

\section{RESULTS}

The results are as follows;

In comparison with the fuel cell operation method, the primary energy reduction amount is large when rated operation is performed.

In terms of the power supply configuration, the total primary energy consumption will be reduced in both cases, but the primary energy consumption of FC houses will increase in nuclear power plants (2010). In the case of the power generation configuration including the nuclear power plant, the primary energy reduction amount is relatively small because the primary energy consumption intensity of the grid electric power is small.

The primary energy reduction rate is about 0.6 to $1.3 \%$ in the case of no nuclear power plants (2012). 